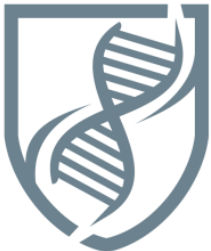

Journal of Bioscience and Applied Research
JBAAR

WWW.JBAAR.ORG

\title{
Gene-Behavior Theory: Relation between behavioral deviation and satellite DNA causing increased selective disease susceptibility within communities
}

\author{
Seif Salah-Eldin Mohammed \\ Department of Immunology and Allergy, Medical Research Institute, Alex, Egypt. \\ seif_sdm@yahoo.com \\ $+201111017413 /+201202025770$
}

\begin{abstract}
The regional differences in the mix of cancers and diseases provoke many questions regarding the causes that control the susceptibility, in this work, it is proven that the behavioral deviance is the main cause for the increased selective disease susceptibility through cross-sectional studies. Theoretically, it is suggested that human leucocyte antigens is a marker for a deviated ancestors, and satellite DNA is an expression to the common-sense and reflects the behavior (The Gene-Behavior Theory), causing increased disease susceptibility if deviated. The conformity approach which used in the human-community theory explain many social and genetic mechanisms, especially, how human-human interactions affect the genetic damage/repair.
\end{abstract}

Keywords: Disease susceptibility. Behavioral deviation. Common sense. HLA. Satellite DNA. Genetic repair. The Gene-Behavior Theory.

\section{Introduction:}

Cancer constitutes an enormous burden on society in more and less economically developed countries alike. The occurrence of cancer is increasing because of the growth and aging of the population, as well as an increasing prevalence of established risk factors such as smoking, overweight, physical inactivity, and changing reproductive patterns associated with urbanization and economic development. ${ }^{(1)}$ But occurrence of this risk factors don't emphasize that the Person will be affected by a disease (cancer as example). And detecting the major leading cause for the continuous increasing of diseases incidence still a big challenge.

Based on GLOBOCAN estimates, about 14.1 million new cancer cases and 8.2 million deaths occurred in 2012 worldwide. Over the years, the burden has shifted to less developed countries, which currently account for about $57 \%$ of cases and $65 \%$ of cancer deaths worldwide. Lung cancer is the leading cause of cancer death among males in both more and less developed countries, and has surpassed breast cancer as the leading cause of

cancer death among females in more developed countries; breast cancer remains the leading cause of cancer death among females .Other leading causes of cancer death in more developed countries include colorectal cancer among males and females and prostate cancer among males. In less developed countries, liver and stomach cancer among males and cervical cancer among females are also leading causes of cancer death. This disparity reflects regional differences in the mix of cancers. ${ }^{(1)}$

The regional differences in the mix of cancer provoke the question of: why a specific disease has high prevalence in a community while shows low incidence in the neighboring countries, although they share similar environment? The question is about what is the factors that draw the susceptibility of a community. 
If the "increased susceptibility" problem will be handled, it is important to be handled in the light of the genetic regions that linked to the inherited diseases as an indicator of increased susceptibility.

The first suspected region is the human leucocyte antigen region (HLA), which is the human major histocompatibility molecule that plays a pivotal role in paternity issues and organ transplantation, ${ }^{(2)}$ in addition HLA is considered accused of association with diseases, and the mechanisms of association has been suggested, By contrast, the basic mechanism by which a particular HLA became a marker of disease is still unknown. However, the disease may occur in individuals which haven't the corresponding guilt HLA type ${ }^{(3)}$ this is controversial, this data lead to another question of: why the certain HLA type may indicate increased susceptibility to a disease, while this disease may occur in presence of another HLA type?

Surprisingly, researches revealed that the Noncoding DNA play a role in disease susceptibility especially satellite DNA (tandemly repeated DNA), satellite DNA has more recently been reconsidered as having various functions. Moreover, due to the repetitive nature of the composing elements, their presence in the genome is associated with high frequency mutations, epigenetic changes and modifications in gene expression patterns, with a potential to lead to human disease. Therefore, the satellite DNA study will be beneficial for developing a treatment of satellite related diseases, and in studying the "increased susceptibility" problem, especially when be known that the exact molecular mechanisms of how satellite DNA can be involved in pathology remain largely unexplored, particularly when satellite DNA is not located in the coding region of the affected gene. ${ }^{(4)}$ I will try to explain the causes of disease outbreak in the light of this two genetic regions.

As an attempt to resolve these questions, the author initiate the Community-Human theory, in this theory it hypothesized that the individuals in community is like cells in body, in order to establish some incontrovertibly facts firstly for the medical community and second for the all communities, as we all share the same medical rules in our body, therefore it will act as a standard perspective.

Comparing the cell-cell interaction in body to human-human interaction in community led to important suggested questions:
-The first question: Is their similarity between cells in body and humans in community?

-The second question: If yes, to what extent humanity freedom, is it has a range like the cell- cell interaction or it absolute?

-The third question: If it has a range, is the significant deviation in human-human interaction lead to disease outbreak in community like what happens in deviated or altered cells in body? And to what extent the deviated behavior can be translated to DNA mutations?

-The fourth question: If the deviated behavior cause DNA change, which type or region of DNA that may reflect this deviation?

-The fifth question: Is there any evidence that any type of failed human-human interaction (Behavioral deviation) lead to corresponding disease?

If there, so relation between human-human interaction and community health can be assumed as a causation. These questions will be answered consecutively in this article.

\section{Human-Community Theory: Novel epidemiological perspective}

According to any perspective can epidemiologist solve Health problems in widely, effective, specific and low cost strategies? At first, epidemiology is often described as the basic science of public health, and for good reason. First, epidemiology is a quantitative discipline that relies on a working knowledge of probability, statistics, and sound research methods. Second, epidemiology is a method of causal reasoning based on developing and testing hypotheses grounded in such scientific fields as biology, behavioral sciences, physics, and ergonomics to explain health-related behaviors, states, and events. However, epidemiology is not just a research activity but an integral component of public health, providing the foundation for directing practical and appropriate public health action based on this science and causal reasoning. ${ }^{(5)}$

Epidemiology was originally focused exclusively on epidemics of communicable diseases, but was subsequently expanded to address endemic communicable diseases and non-communicable diseases. Basic epidemiologic methods tend to rely on careful observation and use of valid comparison groups to assess whether what was observed, also draws on methods from other scientific fields, 
including biostatistics and informatics, with biologic, economic, social, and behavioral sciences. ${ }^{(5)}$

Although epidemiologists and direct health-care providers (clinicians) are both concerned with occurrence and control of disease, they differ greatly in how they view "the patient." The clinician is concerned about the health of an individual; the epidemiologist is concerned about the collective health of the people in a community or population. In other words, the clinician's "patient" is the individual; the epidemiologist's "patient" is the community. ${ }^{(5)}$

\section{Novel perspective (qualitative view)}

In this topic the community will be studied as a one patient "epidemiologist view" but in new fashion, the view of epidemiologist to the community as one patient is a quantitative simple view, a view which had its benefits and contributed to the understanding of some facts. In order to understand some other facts, I have created a qualitative view, by which we will look at society as a human body, comparing the unit of the community to the unit of the body, understanding the large community problems through the known standard human model and vice versa. This inductive view will help connect some of the divergent facts to each other in a relation that we have never imagined before. Thus, based on evidence we easily modulate our act.

The optimum view that facilitate understanding of a community and its health problems, and its corresponding causes, it must be simple, well understood and agreed upon it unanimously, a view that we need to be looks like the IUPAC standardizing nomenclature between chemists in all of the world. It considered a corrective view because it acts as a standard by which we can measure the society state, thus agreement on some corrective facts instead of ignoring it, especially regarding deviated human-human interaction which was thought to be a type of social freedom with no pathologically significant effect. This view is easier to be identified because all humanity share the same body structure and all medical specialists share the basic knowledge of human body without any controversy.

The similarities between human body and community Human in community is like a cell in body, this is the first assumption in this topic, this fact will be accepted as the healthy cells in individual resemble healthy humans in community and vice versa, thus community will be healthy if the individuals interact with each other as normal cells. Later it will be plausible to believe that the optimal and the most advanced nation 'community' system that aim to healthy environment is close to the healthy body system in his harmonic interacted cells which are very advanced, committed and specialized. However, the body still more advanced than any community!

Similarities in molecular level (Molecules of affiliation): Some evidence demonstrates that the developed community is like healthy body, in molecular level, this similarity exists in the level of the DNA, which in the body is similar to the information of a human within a community.

As each one of us has information that is shared with others around (ex/Language), this type of basic information is necessary to facilitate the humanhuman interaction within a particular community. An example of common activated DNA is the HLA molecule which Expressed in all nucleated Cells ${ }^{(2)}$. Therefore, as a foreign individual can be rejected in a community due to his different language, the body can reject a transplanted organ because it has different HLA type.

There are advanced information that need more effort to be required to each different individual in his community, and don't belong to basics, by which we can identify the role of a human in his community, this distinctive knowledge makes this human committed to do a specific career. This is like what happens to a developed cell in its journey to be committed.

To make it closer, during the process of differentiation there is increased expression of lineage-associated genes and repression of lineage inappropriate genes resulting in commitment to differentiation through a specific lineage. (6) Therefore, we can say that the inhibition and activation of genes is like drawing the personality of this cell according to its specialization which created for it, and every cell have its own activated DNA, which make it specialized or committed, which ultimately forms the function and authority of this cell, and the total of these differences encourages us to say that each cell distinct, if not in the general shape or function, but in dimensions (geometry), size and behavior in a specific tissue. The activated DNA which draws the cell shape, function, degree, authority and behavior simulates in the net result the difference between individuals Shape, function, degree, authority and behavior. Basis on that, is the 
behavior of a human can reflect on the behavior of his cells?

The HLA some is co-dominantly expressed, meaning that both maternal and paternal gene product (from both haplotypes) are expressed in the same type and the same cells. ${ }^{(7)}$ Beside the MHC role in adaptive immunity, it play an important role in transplantation biology. ${ }^{(8)}$ Reflecting its major role in the definition of a person like the national ID card.

The infected cell present the antigen through MHC class 1 to be recognized by the immune cells. Virally infected cells is a trigger of cancer if didn't eliminated. ${ }^{(9)}$ Natural killer cells or NK cells are a type of cytotoxic lymphocyte critical to the innate immune system. The role NK cells play is analogous to that of cytotoxic $\mathrm{T}$ cells in the vertebrate adaptive immune response. NK cells provide rapid responses to viral-infected cells, acting at around three days after infection, and respond to tumor formation. Typically, immune cells detect major histocompatibility complex (MHC) presented on infected cell surfaces, triggering cytokine release, causing lysis or apoptosis. NK cells are unique, however, as they have the ability to recognize stressed cells in the absence of antibodies and MHC, allowing for a much faster immune reaction. They were named "natural killers" because of the initial notion that they do not require activation to kill cells that are missing "self" markers of MHC class 1 . This role is especially important because harmful cells that are missing MHC I markers (because the virus try to escape by down-regulating of MHC expression) cannot be detected and destroyed by other immune cells, such as T lymphocyte cells. ${ }^{(10)}$

Through social view. The individual that mentally affected by other factor (mainly by external factors that want to destroy this community internally though minimizing the individuals affiliation, thus they can behave selfishly then will not care about the whole community), will behave like virally infected cell, which if not encountered, it will initiate cancer which is selfish and virulent also. The MHC downregulation phenomenon is a reflection to the Non-integration. The community must behave like immune cells. Basis on that, it hypothesized that the community that accept or legalize a deviated behavior is more prone to cancer. This will be demonstrated later with evidences.

Similarities in molecular level (Molecules of authority): Regarding the authority of a cell, FAS ligand when expressed on a cell means that this cell has the authority of killing, ${ }^{(11)}$ the FAS ligand is like a weapon in a human hand. Apoptosis triggered by Fas-Fas ligand binding plays a fundamental role in the regulation of the immune system. Fas-induced apoptosis and the perforin pathway are the two main mechanisms by which cytotoxic $\mathrm{T}$ lymphocytes induce cell death in cells expressing foreign antigens. (11) This mean that $\mathrm{T}$ cytotoxic cell has high authority than other cells that judged dangerous, by contrast, cells in immune privileged areas (as example/ the cornea, brain or testes) express Fas ligand and induce the apoptosis of infiltrating lymphocytes (that have FAS ligand also). It is one of many mechanisms the body employs in the establishment and maintenance of immune privilege. (12) This demonstrate that the cells in immune privileged areas has higher authority than lymphocytes. Although both types of cell express FAS ligand, but it seems to be there are some molecular differences which make one cell has higher authority than the other, although the two originate genetically from the same zygote. This system is similar to what happens in the military system towards the higher ruler's authority, where stabilized community prevent some military force elements from entering the country's highest authorities having a weapon!

\section{Epithelial cells is an example of the major simple} population: The healthy human body considered great nation with cooperated populations "tissues", there are every specialized branch, the cells of high number as epithelial cells resemble the base of any community, and may be described as a naïve with simple Function, but draw the whole body shape. Interestingly, the most common Cancers which include all those in the breast, prostate, lung, pancreas and colon, are derived from epithelial cells and it defined as "Carcinoma". ${ }^{(13)}$ In community, it can be destroyed when an external system tries to manipulate the ideas of the majority of this community which often naive, thus initiation of deviated groups that can be used to destroy this community, these terrorist groups are considered carcinoma according to our perspective. As they behave like cancer, especially in the point of affiliation!

The liver in body is like the factories in community: The synthesis is one of the major functions of Hepatocyte that manufactures serum albumin, fibrinogen, and the prothrombin group of clotting factors (except for Factors 3 and 4). It is the main site for the synthesis of lipoproteins, ceruloplasmin, transferrin, complement, and 
glycoproteins. Hepatocytes manufacture their own structural proteins and intracellular enzymes. Synthesis of proteins is by the rough endoplasmic reticulum (RER), and both the rough and smooth endoplasmic reticulum (SER) are involved in secretion of the proteins formed. The endoplasmic reticulum (ER) is involved in conjugation of proteins to lipid and carbohydrate moieties synthesized by, or modified within the hepatocytes. (14) Thus, hepatocyte can be considered a skilled manufacturer in a high-tech factory where ores turn into products. In addition, this manufacturer can be turned on the military services (military factory $=$ ) as a response for acute phase.

The acute-phase response is a nonspecific process that may occur in the initial host response to injuries, infections, ischemic necrosis, or malignancy. It is initiated by the activation of local macrophages and other cells (including fibroblasts and endothelial cells), leading to the release of mediators such as TNF- $\alpha$, IL- 6 , and IL- $1 \beta$. These, in turn, cause systemic changes including hepatic release of a range of plasma proteins (including CRP), activation of complement proteins, and various metabolic changes. ${ }^{(15)}$ These military products that produced from the liver is used in the immune response to safe the whole body from any invaders or inflammations.

The kidney in body is like the cleaner in community: The nephron is the basic structural and functional unit of the kidney. Its chief function is to regulate the concentration of water and soluble substances like sodium salts by filtering the blood. One of the major functions of nephron is the elimination wastes from the body and reabsorbing what is needed and excreting the rest as urine. (16) Nephron is considered advanced cleaning agent where it works with the option of recycling, more developed communities tend to the recycling in order to protect environment and sustain its resources. Recycling is the process of converting waste materials into new materials and objects. It is an alternative to "conventional" waste disposal that can save material, recycling can prevent the waste of potentially useful materials and reduce the consumption of fresh raw materials, thereby reducing: energy usage, air pollution (from incineration), and water pollution (from land filling). Recycling is a key component of modern waste reduction and is the third component of the "Reduce, Reuse, and Recycle" waste hierarchy. ${ }^{(17)}$ basis on that, it is expected that communities that do not give importance to the cleaner "hygienist", medically is more prone to have high incidence of diseases especially renal failure, environmentally has depletion in its resources and economically is suffering from debt.

Endocrine system in body is like the remote sensing engineers in community: Endocrine signaling is the phenomenon of biochemical processes serving to regulate distant tissues by means of secretions directly into the circulatory system. The endocrine system is the collection of glands of an organism that secrete hormones directly into the circulatory system to be carried towards distant target organs. The major endocrine glands include the pineal gland, pituitary gland, pancreas, ovaries, testes, thyroid gland, parathyroid gland, and adrenal glands. ${ }^{(18)}$ The secretory cell that found in this glands is similar to the advanced communications engineer which has the ability of remote sensing and signaling to a receiver, this receiver in body is like the target cells which have the corresponding receptor "antenna ".

The circulatory system in body is like the roads in community: The circulatory system, also called the cardiovascular system is a closed system connecting a pump to blood vessels (i.e., arteries, capillaries, veins). The heart serves as the pump that moves blood through blood vessels thereby providing the needed oxygen and nutrients to the body, to and from the cells in the body to provide nourishment and help in fighting diseases. ${ }^{(19)}$ The vessels in body represents the road network in community, but in a more complex and evolving form.

The immune system in body is like military forces in community: Every mission can be done by the military forces towards their community, the same can be done by the immune system towards its body. The immune system has evolved to protect the host from a universe of pathogenic microbes that are themselves constantly evolving. The immune system also helps the host eliminate toxic or allergenic substances that enter through mucosal surfaces. Central to the immune system's ability to mobilize a response to an invading pathogen, toxin or allergen is its ability to distinguish self from non-self. The host uses both innate and adaptive mechanisms to detect and eliminate pathogenic microbes. Both of these mechanisms include self-nonself discrimination. Cells of immune system is considered a fascinating advanced Military system. Antigen presenting cell (APCs) as example, identify 
Non-self-antigen, process and present it to other effector cells like T and B lymphocytes. ${ }^{(20)}$

The thymus in body is like the military central training center in community: In addition, some types of this high ranked cell (APCs) has a function of training $\mathrm{T}$ cell to how discriminate self and non-self-antigens in the training site "thymus" Immature $\mathrm{T}$ cells, known as thymocytes (thymus cells) because of their site of maturation, pass through defined developmental stages in specific thymic microenvironments as they mature into functional $\mathrm{T}$ cells. The thymus is a specialized environment where immature $\mathrm{T}$ cells generate unique antigen receptors ( $\mathrm{T}$ cell receptors, or TCRs) and are then selected on the basis of their reactivity to self MHC-peptide complexes expressed on the surface of thymic stromal cells. Those thymocytes whose T-cell receptors bind self MHC-peptide complexes with too high affinity are induced to die (negative selection), and those thymocytes that bind self MHC-peptides with an intermediate affinity undergo positive selection, resulting in their survival, maturation, and migration to the thymic medulla.

Most of the $\mathrm{T}$ cells that engage strongly to selfantigen are judged to undergo imuunoregulation, anergy or programmed cell death (Apoptosis) ${ }^{(21)}$ this tough judgments is necessary to protect the whole human body from autoimmune diseases. Basis on that, it is predicted that the community that doesn't give the full care to their younger generations is more prone to acts of terrorism and sabotage either from individuals that attack community or licensed military subject that wrongly use their weapons toward their community, and clinically, I hypothesize that it is more prone to autoimmune diseases outbreak. Therefore, it is preferable to have children from married parents not from non-married parents to ensure that full care is received. And Basis on that, I assume that communities that accept cohabitation has higher prevalence of autoimmune diseases! The psychological effect of cohabitation and the driven assumption will be demonstrated and studied later.

\section{The non-altered cell in community is like a man} of non-altered common sense in community: Finally, it is proposed that the non-altered cell in human body is like behaviorally non-deviated person in community (person without alteredcommon sense), this foundation will be useful in later clarifications.
There are more than one evidence that human cells interaction in normal body is extremely optimal and advanced, one important note is that the human body definitely is more advanced than community, by other words, when the community became more developed, it became more similar to the healthy human body.

This derived examples revealed that there are similarities between developed community and human body, and explained that the comparing of the community with the human body is an acceptable theory, by which many facts can be derived in the social, medical and administrative fields.

\section{Cell-cell interaction and human-human}

interaction has a range

Cell adhesion plays a pivotal role in numerous diverse biological processes that occur within the vasculature, including inflammation and cancer metastasis. Cell-cell interactions are required to be highly specific in nature for proper regulation of the various physiological events. For instance, inflammatory processes normally protect the body from infections by foreign pathogens, but when dysregulated, leukocyte migration to healthy tissues can lead to unwanted disorders and pathological conditions, including but not limited to ischemiareperfusion injury, acute respiratory distress syndrome, and some types of arthritis. Similarly, inappropriate activation or defective modulation of the hemostatic mechanism can lead to the formation of platelet rich thrombi that can compromise the patency of blood vessels and precipitate pathological states such as myocardial infarction and stroke. In blood-borne metastasis, tumor cells use the vascular system as transportation to a secondary organ where a new metastatic colony is generated. ${ }^{(22)}$

Cell adhesion is undesirable as it pertains to tumor cell intravasation and extravasation through the blood vessel wall, yet it is advantageous in the host defense system of natural killer cells against tumor cells within the blood stream. ${ }^{(22)}$

As cell-cell interactions are required to be highly specific in nature for proper regulation of the various physiological events, the human - human interaction are required to be highly specific in nature. Accumulating evidence suggests that failed cell-cell interaction lead to pathological condition like autoimmune diseases and malignancy, two of the most critical pathological disorders affecting 
humankind today. ${ }^{(23)}$ Shall I suppose that the failed human- Human interaction has a causative role regarding initiation of diseases? If yes, how to connect?

A priori, cell- cell interaction is tightly related to genes signaling, thus, what makes genes send failed signals?! And what is the real factors by which a community individuals are more susceptible to failed genetic signals than the neighboring communities?

According to the community-human body view and basis on the previous data (see box 1 and table1), I assume that human-human interactions is translated genetically to an alteration in a specific region, this region responsible for increasing or decreasing disease susceptibility in narrow and wide scale (individually and socially), I will try to study this assumption in details later. In addition, this alteration is assumed to be the main cause of failed signaling between cells in body.

In immune system the T cell-APC interaction results in the stable organization of signaling molecules into an immune synapse is controlled by the avidity (the combined affinity of all cell-cell interactions) of the cellular interaction. ${ }^{(23)}$ Recall that the avidity strength mustn't be too high or too low, ${ }^{(20)}$ therefore the interaction must be in a range. The coreceptors CD4 and CD8, which are found in the central supramolecular activating complex (cSMAC), stabilize the interaction between TCR and MHC by binding MHC class II and MHC class I molecules, respectively.

The failed human-human interaction has a pathological effect: The Interactions between adhesion molecules and their ligands help to sustain the signals generated by allowing long-term cell interactions, ${ }^{(23)}$ which means that the interaction has optimal time, Therefore, Any Significant change in the normal interaction lead to pathological disorder, which may be immunocompromised or hyperimmune response, giving the pathogens the ability to spread within the deviated community, especially the weak pathogen that wasn't dangerous before. This may be an explaining for the question of: Why new microbes appear? And why appear in specific population causing endemic diseases.

In social view, the failed human-human interaction in a community increases the opportunity of the intellectual and bloody invasions towards it.
This invasion was difficult in presence of the optimal human-human interaction in this community. However, it is impossible for members of community to agree in the same right behavior that does not deviate from it, and this in itself is a description of cancerous behavior, as all cells of cancer share the same deviated behavior and distorted shape and this isn't my intention.

The differences between individuals is accepted in the range that guarantee community services: It's good to have our model, the body, which normally has cells of different shape, function and behavior. This led us to confirm that every individual must have his own different shape, function and behavior, but the differences between cells is sound in the range that ensures the safety of the entire body. Therefore, the differences in the individual's behavior must be in the range that ensures the service of society as a whole.

The cells are united to serve the whole body in coordinated interactions, this coordination is measured totally through body biomarkers level. Therefore, the coordinated human-human interaction also must have a markers. I suggest the prevalence of diseases to be the marker of the human-human interactions in a community. The increased prevalence (high susceptibility) will indicate a highly deviated human-human interaction, while decreased prevalence (Low susceptibility) will indicate less deviated human-human interaction, this will be proven by evidence later.

To clarify: Biological markers (biomarkers) have been defined as "cellular, biochemical or molecular alterations that are measurable in biological media such as human tissues, cells, or fluids. A pivotal note is that the biomarkers have an optimal mean within a reference range. ${ }^{(24)}$ And cells interact with each other by many types of communication tools as junctions, adhesion molecules, hormones, cytokines and their corresponding receptors, in order to maintain their distance, adherence level, biological functions in certain amount and time. Therefore, detection of biomarker level determine to what extent the corresponding cells are coordinated. How?

A driven example for clarify, at first, is all cells demand the same quantity of glucose? The mammalian brain depends on glucose as its main source of energy. In the adult brain, neurons have the highest energy demand, ${ }^{(25)}$ this reveal that there is a cells have lowest energy demand. Although 
there is a difference in the energy demand, the glucose level has preferred mean value and allowable range between a maximum and minimum value $(70-140 \mathrm{mg} / \mathrm{dl})$, this is a value which represents coordinated cell-cell interaction regarding energy, the value above and below reference range represent pathological condition (see box 1). Recall the characteristics of the cancer cells, when it captures nutrients, especially sugar, in behavior that is considered oblique.

This example confirm the notion of the humanhuman interaction (behavior) may has optimal value and must located within a permitted range, and I assume that legalization of deviated behavior in a community is like crossing the allowable range from a deviated cells, which leads to a corresponding pathological condition outbreak in the whole community, this gives partial explanation to the phenomenon of the regional differences in the mix of cancer. As every community has its own range of interactions. arrangement in a tissue, behavior of cell, behavior of immune cells to the altered cell, behavior of immune system toward aggressively active immune cell, the spelled enzymes from dead cells, biochemical products of specific cell population, cytokines that manage and direct Cells activity, etc. similarly we can detect the deviation in an individual through a markers. In human body when the biological indicator value cross the reference range it called (abnormality), in community the deviation in human-human interaction is called (obscenity), the real definition of obscenity is fit together with our insight will be explained later.

Till now, the question of: is there a similarities between community and human body? Is answered with "yes", and the question of: is the humanhuman interaction has absolute freedom or it has a range? Is answered with "yes" it has a range, crossing this range may represented by a pathological condition like what happened in the body.

These body biomarkers may be number of cell population, Shape of individual cell, shape of cells

\section{Box 1: Aristotelian view, still works}

The concept of optimal value (mean value) to an act which intermediate between two extremes (reference range) is described before in other science in the theory of Aristotle as he Said: the golden mean or golden middle way is the desirable middle between two extremes one of excess and the other of deficiency. For example, in the Aristotelian view, courage is a virtue, but if taken to excess would manifest as recklessness, and, in deficiency, cowardice. ${ }^{(26)}$ This theory will be applied regarding "Community-Human view" to help detecting the optimal and deviated human-human interaction. Note that the values between the two extremes are acceptable, only the values above the two extremes are rejected and hypothesized to be a cause of increases disease susceptibility (see table 1).

In the table, I tried to connect between the different views for the same concept, interaction range is applied in social, medical, molecular perspectives, the relation can be assumed as follow:

1- The golden mean "virtue "in community is related to non-altered DNA "genetic common sense" and related to immunized healthy community (see the white middle column).

2- The range above and below the golden mean is acceptable, the range between two extremes regarding human-human interaction is related to the genetically altered regions which followed by genetic repair, in contrast it related to controlled health state.( see the two grey columns which are surrounding the white column, the two thick lines represent the range outlines).

3- The value above and below the allowable range "reference range in biomarkers evaluation" is refused, and highly related to the deviated human-human interactions which assumed to be related to the permanent genetic alteration "vigorous breaking in the gene common sense ", thus inherited to further generation causing increased susceptibility to diseases (see the two darker columns).

This data theoretically support the assumption of: the deviated human-human interaction is highly related to specific genetically altered region that may be inherited to further generations causing a variety of disease either known or unknown.

At the last part of our journey in this topic, I will proof the relation between the behavioral deviance and increased diseases susceptibility, In the case of acceptance of the new proven insight, it will be recommended for detecting the range of human-human interaction that sustain community health, uniformly, convincingly and without contradiction. In addition, the new insight will help different thinkers to agree upon some facts which disputed, and detecting the golden mean regarding human-human interactions. This golden mean is assumed to be the route of healthy community.

Many thinkers differed about the definition of obscenity, and this is because of many factors, I will explain some of them later Interestingly, the only definition of obscenity that fit to our insight is found in the Arabic dictionary, which define obscenity as "Any act which exceeded the allowable limit" (27) 


\begin{tabular}{|c|c|c|c|c|c|}
\hline \multirow{2}{*}{$\begin{array}{l}\text { Interactions range } \\
\text { Cell-Cell } \\
\text { Interaction } \\
\text { "biomarkers level" } \\
\text { (Medical) }\end{array}$} & \multirow{2}{*}{$\begin{array}{l}\text { Lower inter-action } \\
\text { Value } \\
\text { Abnormality }\end{array}$} & \multicolumn{3}{|c|}{ Allowable range of interaction } & \multirow{2}{*}{$\begin{array}{r}\text { Higher inter-action } \\
\text { Value } \\
\text { Abnormality }\end{array}$} \\
\hline & & Lower limit & Mean Value & Upper limit & \\
\hline $\begin{array}{l}\text { Human-Human } \\
\text { interaction } \\
\text { (Social) } \\
\end{array}$ & $\begin{array}{l}\text { Deviated Human- } \\
\text { Human interaction } \\
\text { (Obscenity) }\end{array}$ & Lower virtue limit & $\begin{array}{l}\text { Virtue(golden mean) } \\
\text { (common sense) }\end{array}$ & Higher virtue limit & $\begin{array}{r}\text { Deviated Human- } \\
\text { Human interaction } \\
\text { (Obscenity) }\end{array}$ \\
\hline $\begin{array}{l}\text { DNA State } \\
\text { (Molecular) }\end{array}$ & $\begin{array}{l}\text { Inherited altered } \\
\text { DNA }\end{array}$ & $\begin{array}{l}\text { DNA alteration } \\
\text { followed by DNA } \\
\text { repair }\end{array}$ & $\begin{array}{l}\text { Non-altered DNA } \\
\text { (Optimal Sequence) }\end{array}$ & $\begin{array}{r}\text { DNA alteration } \\
\text { followed by DNA } \\
\text { repair }\end{array}$ & Inherited altered DNA \\
\hline $\begin{array}{l}\text { Community Health } \\
\text { "Prevalence" } \\
\text { (Susceptibility) }\end{array}$ & $\begin{array}{l}\text { Disease outbreak } \\
\text { High susceptibility }\end{array}$ & $\begin{array}{l}\text { Controlled health } \\
\text { state }\end{array}$ & Optimal Health state & $\begin{array}{r}\text { Controlled health } \\
\text { state }\end{array}$ & $\begin{array}{r}\text { Disease outbreak } \\
\text { High susceptibility }\end{array}$ \\
\hline
\end{tabular}

\section{Deviated human-human interactions is the main cause for disease susceptibility either communicable or non-communicable}

"Epidemiological research is more important than basic research in the modern therapeutic medicine strategies, as it searches for causes of thediseases in societies " said mohamed samy afifi, professor of immunology in a lecture about causality in the department of immunology and allergy at Medical Research Institute in Alexandria.

How to detect a cause? A cause is defined to be an object followed by another, a causal complex may be seen as a conjunction of factors that only jointly are sufficient for bringing about the effect. There may be several different causal complexes that are all sufficient for bringing about the effect; hence, none of them are necessary. ${ }^{(28)}$

Guidelines developed to draw a link between pathogen and disease were first formalized by German physicians Robert Koch in 1890 which revisited by Alfered S. Evans in $1975^{(29)}$, and by Austin Bradford Hill in 1965, ${ }^{(30)}$ Koch's postulates has a limitation in relation to virus, today many scientists use the Bradford Hill criteria, which were developed to establish causation between a specific factor-environmental or otherwise-and a disease. ${ }^{(31)}$

However, the collected data about hill criteria was demonstrated as follow: Hill Criteria is widely accepted, but at the same time they have been quite controversial, hill himself explicitly denied that the guidelines should be termed criteria, but rather Viewpoints. Likewise advocates of the Hill criteria state that although they are not rigid criteria that must all be fulfilled, they still give positive support to inferences about causality. ${ }^{(28)}$ Critics argue that the criteria are obscurely described and partly overlapping (32-33-34), or that none of the criteria (except temporality) apply in all circumstances. By the same token, it has been argued that they should not be seen as rules, but rather as values that can be interpreted and weighed differently by different scientists. ${ }^{(28)}$ I think that the criteria will be fully accepted when we put the missed part, which is the genetic susceptibility that controlled by the behavior, In contrast, this novel finding will resolve some controversial issues and complete the picture of causality.

The Bradford Hill criteria, which were developed to establish causation between a specific factorenvironmental or otherwise-and a disease. The criteria include strength of association, consistency (replication by other laboratories), specificity, temporality (whether exposure preceded disease), biologic dose gradient, plausibility (credible scientific mechanism), coherence with other evidence, experimental evidence, and analogy, ${ }^{(30)}$ therefore the detecting of the cause that affects disease susceptibility will be conducted in the light of these nine criteria. 
The suggested risk factors is controlled by the genetic susceptibility

In the past two decades, the study of viruses has contributed greatly to the understanding of cancer biology. However, determining that a virus is a cause or a cofactor in cancer is another story, and it is slow, difficult work. There are many factors that are difficult to determine its relation to an effect which may be association or causation. ${ }^{(28)}$

Information on cancer causation has come from investigation of the patterns of cancer in human populations and the induction of tumors in experimental animals following treatment with cancer-causing agents. The most important human carcinogens include tobacco, asbestos, aflatoxins and ultraviolet light. Almost $20 \%$ of cancers is associated with chronic infections, the most significant ones being hepatitis viruses (HBV, HCV), papillomaviruses (HPV) and Helicobacter pylori. There is increasing recognition of the causative role of lifestyle factors, including diet, physical activity, and alcohol consumption. Genetic susceptibility may significantly alter the risk from environmental exposures. ${ }^{(35)}$ Thus, what is the factor that affects this genetic susceptibility? As example, lung cancer is mainly attributable to tobacco use, and genes linked to the metabolism of tobacco borne carcinogens have been studied as hereditary risk factors in lung cancer, but they have not been readily linked to risk. ${ }^{(36)}$ In addition, I found that countries with a high incidence of lung cancer do not consume tobacco in correlated rates (see table 2)

\begin{tabular}{|l|l|l|}
\hline \multicolumn{1}{|l|}{$\begin{array}{l}\text { Table 2: Comparison between Lung Cancer incidence and } \\
\text { tobacco consumption in some countries. }\end{array}$} \\
\hline Country & $\begin{array}{l}\text { Incidence of lung } \\
\text { cancer (Per } \\
100,000 \\
\text { Population) })^{(37)}\end{array}$ & $\begin{array}{l}\text { Number of } \\
\text { cigarettes smoked } \\
\text { per person per } \\
\text { year: age } \geq 15 . .^{(38)}\end{array}$ \\
\hline United States & 54.6 & 1083 \\
\hline Poland & 53.1 & 1396 \\
\hline Denmark & 41.8 & 1378 \\
\hline United Kingdom & 41.1 & 826 \\
\hline China & 34.1 & 4124 \\
\hline Turkey & 29.1 & 1580 \\
\hline Algeria & 10.4 & 1041 \\
\hline Zimbabwe & 10.2 & 134 \\
\hline Egypt & 6.3 & 1215 \\
\hline Iran & 5.2 & 836 \\
\hline Kenya & 3.5 & 257 \\
\hline
\end{tabular}

Individually, it probably that the affected person with lung cancer which subjected to the real cause is a smoker, which means that the two factors may occur in the same time not smoking proceed cancer as a cause (temporality), thus it suggested that the relation between tobacco and lung cancer is association not causation. And the real cause still under investigation.

Another example regarding viruses, viral hepatitis is an inflammation of the liver caused by a virus, By contrast up to 30 percent of people infected with HCV successfully clear the virus from their systems within six months after being infected (immunocompetent people), ${ }^{(39)}$ despite the entry of the virus, there are no infection, this immunocompetent patients clear the virus spontaneously! And focus the light on the genetic susceptibility.

At present, accepted causal associations between viruses and human cancer are HPV and cervical cancer; human $\mathrm{T}$ lymphotrophic virus type-1 (HTLV-1) and adult T-cell leukemia and lymphoma; hepatitis $\mathrm{B}$ and $\mathrm{C}$ and liver cancer, Epstein-Barr virus (EBV) and nasopharyngeal cancer, Burkitt's and Hodgkin's lymphomas, and some non-Hodgkin's lymphomas; and human herpes virus 8 (HHV-8) and Kaposi's sarcoma, according to the American Society of Clinical Oncology. Other viruses under investigation. By contrast, many years may pass between initial infection and tumor appearance, and most infected individuals do not develop cancer, although, in some cases, immunocompromised people have higher risk of virus-associated cancer. ${ }^{(31)}$

In addition, the idea that synthetic chemicals such as DDT are major contributors to human cancer has been inspired, ${ }^{(41)}$ but the evidence showed why this is not true. The vast bulk of chemicals ingested by humans is natural. For example, $99.99 \%$ of the pesticides we eat are naturally present in plants to ward off insects and other predators. Half of these natural pesticides tested at the MTD are rodent carcinogens. Humans also ingest large numbers of natural chemicals from cooking food. Over a thousand chemicals have been reported in roasted coffee: more than half of those tested (19/28) are rodent carcinogens. (43) There are more rodent carcinogens in a single cup of coffee than potentially carcinogenic pesticide residues in the average American diet in a year, and there are still a thousand chemicals left to test in roasted coffee. This does not mean that coffee is dangerous but rather that animal cancer tests and worst-case risk assessment, build in enormous safety factors and should not be considered true risks. ${ }^{(41)}$ 
The reason humans can eat the tremendous variety of natural chemical "rodent carcinogens" is that humans, like other animals, are extremely well protected by many general defense enzymes, most of which are inducible (i.e., whenever a defense enzyme is in use, more of it is made). ${ }^{(42)}$ This information confirm that there is other cause increase the genetic susceptibility to diseases, this genetic susceptibility may significantly alter the risk from environmental exposures. And many of the suggested risk factors is belong to association more than causation, or belong to risk factor category not to main causes.

This data provoke the question of: what is the real factors that determine the community immuno-competency, by other wards, what is the cause which makes a person is less susceptible to particular diseases while makes the other more susceptible to be affected by pathological conditions? And if determined, is this cause can be weighted by hill criteria?

The cause that sustain the human immunocompetency is very significant cause, which if well-handled will reduce the predicted number of affected individuals in the future. According to our theory (recall table 1), it hypothesized that deviated human-human interaction (Obscenity) is a direct cause for pathological genetic alteration leading to disease susceptibility, this alteration can be inherited among generations, the evidence will be derived later.

The legalization is an important factor regarding the genetic changes occurred in the whole community

Either the acceptance of deviated behavior or neglecting it is like $\mathrm{T}$ cell ignoring to virally infected cell, or failed response towards deviated or virally infected cell. If this happened, the human body will be more susceptible to be affected by disease and similarly the community. In addition, the step of angiogenesis in body affected by cancer has another social dimensions.
The enrichment of a cancerous tissue is like the acceptance of a deviated group in community: New growth in the vascular network is important since the proliferation, as well as metastatic spread of cancer cells depends on an adequate supply of oxygen and nutrients and the removal of waste products. New blood and lymphatic vessels form through processes called angiogenesis and lymphangiogenesis, respectively. Angiogenesis is regulated by both activator and inhibitor molecules. More than a dozen different proteins have been identified as angiogenic activators and inhibitors. Levels of expression of angiogenic factors reflect the aggressiveness of tumor cells. The discovery of angiogenic inhibitors should help reduce both morbidity and mortality from carcinomas. Thousands of patients have received antiangiogenic therapy to date. Despite their theoretical efficacy, antiangiogeic treatments have not proved beneficial in terms of long-term survival. There is an urgent need for a new comprehensive treatment strategy combining antiangiogenic agents with conventional cytoreductive treatments in the control of cancer. ${ }^{(43)}$

The vascularization enrichment function is like the rights that given by community to the deviated people which support their existence, help in publishing their behavior and increase their numbers. In this article, it was found that the community that legalize and protect deviated individuals is more susceptible to diseases than the neighboring communities that didn't legalize that deviated action.

Side by side, the community that fail in preventing deviated behavior is like the community that legalize the deviated behavior, as the two give the same result. It found that the community that fail in preventing deviated behavior has higher cancer incidence. In addition, the diseases susceptibility is not rigid, it seems to be specific, I will demonstrate later that the specific deviated behavior cause specific disease susceptibility in a community that legalize the deviated behavior. 


\section{The Satellite DNA-Behavior Theory}

Basis on our new insight, it is assumed that the human behavior is represented in a specific gene region, thus when inherited, it transmit the disease susceptibility to the further generations, and this provoke a question of: what is the genetic regions that considered a mirror picture for the behavior?

MHC molecule is merely a marker for the ancestor deviation

The Major histocompatibility (MHC) molecule that guilt by association with specific disorders, ${ }^{(3)}$ is the first suspected region which will be reestimated in this topic according to our new perspective.

MHC molecule is co-dominantly expressed, meaning that both maternal and paternal gene product (from both haplotypes) are expressed in the same type and the same cells. ${ }^{(18)}$ Is this clue answer the question of why the daughter of women who affected by breast cancer is more borne to breast cancer? Partially yes! As it receive the half genetic material (altered and represent the high susceptibility) from her mother. This genetic region must be co-dominantly expressed. The question is: is the HLA region represent the susceptibility? Or represent other thing.

It is now over forty years since the first associations between particular HLA antigens and disease susceptibility were described, several hundred diseases have now been reported to occur more frequently in individuals with particular HLA genotypes. These diseases include a broad spectrum of immune-mediated diseases involving all major organ systems, certain malignancies, infectious diseases and more recently, adverse reactions to particular drugs. ${ }^{(3)}$

\section{Suggested mechanisms for HLA association/} causation: What mechanisms might underlie a clearly established HLA association with a given disease? In terms of the role of HLA molecules in peptide presentation to $\mathrm{T}$ cells, a causative role of HLA in terms of presentation of a diseasetriggering self-peptide, nonself-peptide or alteredself-peptide at the site of disease is clearly an attractive hypothesis. Alternatively, HLA may play a causative role via influence on the T-cell repertoire, including Treg cells, resulting in potential autoreactivity. Other aspects of HLA biology may additionally or alternatively influence the disease process. Finally, the associated HLA polymorphism may play no direct role, and the actual disease-predisposing polymorphism may be in linkage disequilibrium with the initially reported HLA association, which merely acts as a marker. ${ }^{(3)}$ The HFE association with hereditary haemochromatosis is a classic example, in which the original association was reported to be with HLA-A and B, ${ }^{(44)}$ prior to discovery of the HFE gene. ${ }^{(45)}$ In addition, other genetic polymorphisms may also contribute to disease susceptibility, even when HLA polymorphisms play a direct, significant role. ${ }^{(3)}$

Surprisingly and frustratingly, clear identification of the underlying mechanisms resulting in a causative role for HLA polymorphism in the molecular immunopathogenesis of individual HLA-associated diseases remains the exception rather than the rule. ${ }^{(3)}$ However, basis on the new view, the relation between HLA and disease can be confirmed as merely a marker, which related to a disease as association not as a causation, why?

The HLA typing, is recognized throughout the world as the single most discriminating test for determination of paternity issues. ${ }^{(46)}$ therefore HLA is a considered representative ID for a family line or Strain, this note will be taken as a clue, where I assume that the ancestor of a family has a deviated behavior, this deviated behavior translated genetically into change in a genetic region which is the trigger of a disease predisposition, the altered genetic region is transmitted to the progeny side by side to the codominant HLA. The disease may occur with any type of HLA but mainly will occur in a family with this specific alteration in the genetic region that represent the susceptibility, Therefore the HLA not a marker of disease, it may be a marker of a family line with a specific strongly deviated behavior or affected by a bad behavior from others, this explain why the disease may occur in other strains that don't share the type of HLA, they just share the deviated behavior. This assumption need to be re- illustrated in the light of genetic instability and genetic repair.

Researches confirm the notion of non-MHC susceptibility genes: Another supportive research mentioned that many mysteries remain with respect to the genetics of Type I Diabetes (T1D) and other diseases controlled by MHC susceptibility genes in concert with other non- 
MHC genes. We propose a new paradigm for T1D MHC genetics, on the basis of our analysis of both the historical and recent literature on this disease. There is good evidence that the T1D MHC susceptibility gene is recessive, but that other, non-MHC susceptibility genes are required for T1D to occur. (47) However, if these assumptions are true, what is the real genetic loci (non-MHC genes) that related to the diseases as a cause?

If this loci assumed to be related to human behavior, it must has/or reflects the characteristics of behavior, which may be:

1- Having a repetitive nature of the composing elements to reflect the repetitive nature for a behavior.

3-Associated with high frequency mutations, epigenetic changes and modifications in gene expression patterns as a response to vigorous deviated interactions.

4-Has no effect in the phenotypic characteristics as it represents the moral qualities not the formal qualities of a human.

5-Inherited co-dominantly to explain the inheritance from both mother and father.

6-Influences the protein-coding DNA through the messages they make (RNA), thus if deviated will cause epigenetic damage, like the ugly messages received from a deviated individual towards his community.

7- has the ability to cause expansion or contraction in DNA structures, which may be a reflection of the genetic repair and genetic damage, as the human behavior may change irreversibly to two opposite manners (ex: accepting / refusing a deviated interaction).

8- Related to cancer and hereditary disorder, as I confirmed the relation between behavioral deviance and increased susceptibility of hereditary diseases (at the last part of this work), therefore, this genetic region must has a role in carcinogenesis in individuals and increased cancer prevalence within communities (increased susceptibility).

These characteristics and more are available in satellite DNA except its relation to the human behavior which it assumed in this topic as a result of the new insight.

Satellite DNA is a mediator between the behavioral deviation and the increased disease susceptibility

According to the new perspective, the similarities in the molecular level between cell in body and human in community can be assumed as follow:
As the human has a formal and moral qualities, the cell also must has formal and moral qualities, formal qualities come from "phenotypic = coding DNA" and thus the moral qualities must come from "Non- phenotypic = non-coding DNA". Therefore, the relation between the human moral qualities and his non-coding DNA can be assumed, giving the opportunity to connect between the moral Deviation and diseases susceptibility through the non-coding DNA.

What is Satellite DNA? Only a tiny percentage of human DNA is coding for proteins, whereas the non-coding DNA, transposons and transposon-derived elements make up the majority of the genome. ${ }^{(48)}$ This fact was first discovered already in the 70's of the last century. Later, the efforts of the Human Genome Project resulted in the estimation of the percentage of non-coding DNA of the human genome as 98-99 \%. (4) This somewhat surprising fact led Susumi Ohno (1972) to suggest the notion of «junk DNA», referring to the idea that most genomic DNA has no use for the organism. ${ }^{(49)}$

Satellite DNA in genome organization: In humans, recent estimations based on the results of the human genome project suggest that about $70 \%$ of the genome is represented by repetitive and repeat-derived DNA elements. ${ }^{(50)}$ The repeated sequences can be divided into two categories:

- The «interspersed repeated sequences», when the repeating copies are dispersed over the genome.

- The «tandem repeated sequences» (also called satellite DNA), when the repeating copies are adjacent to each other. ${ }^{(51)}$

Satellite DNA is a diverse class of highly repetitive units, accounting for approximately $10-15 \%$ of all repetitive DNA sequences in the human genome. ${ }^{(52)}$

Satellite DNA, also known as tandemly repeated DNA, consists of clusters of repeated sequences and represents a diverse class of highly repetitive elements. ${ }^{(54)}$ Satellite DNA can be divided into several classes according to the size of an individual repeat: microsatellites, minisatellites, midisatellites and macrosatellites. ${ }^{(53)}$

Characteristics of satellite-DNA and behavior is the same: Originally considered as «junk» DNA, satellite DNA has more recently been reconsidered as having various functions. Moreover, due to the repetitive nature of the 
composing elements, their presence in the genome is associated with high frequency mutations, epigenetic changes and modifications in gene expression patterns, with a potential to lead to human disease. ${ }^{(54)}$ Therefore, the satellite DNA study will be beneficial for developing a treatment

of satellite related diseases, such as FSHD, neurological, developmental disorders and cancers. ${ }^{(4)}$

In recent work it has been reported that the megabase sized deletion of non-coding sequences in mice has no phenotypic effect. ${ }^{(55)}$ As it may represent the moral qualities.

The ENCODE project has systematically mapped regions of transcription, transcription factor association, chromatin structure and histone modification. These data allowed researchers to assign the biochemical functions for $80 \%$ of the human genome, in particular to noncoding regions, highlighting an evidence of the functionality of non-protein-coding DNA. One of the demonstrations is the transcription of most nonprotein coding DNA into RNA. ${ }^{(56)}$ Only $4 \%$ of the 65000 RNAs produced by genome are coming from exons. ${ }^{(57)}$ As human behavior can sent a moral messages to the surrounding, I assume that the cell can sent moral messages to the surrounding cells through the non-protein coding regions.

Much further evidence of functionality of nonprotein coding DNA has been shown. For example, the introns regulating an alternative splicing. ${ }^{(58-59)}$ are involved in gene expression. ${ }^{60-}$ 61-62) and chromatin organization. (63) Some pseudogenes are involved in lipid metabolism. ${ }^{(64)}$ In the process of protein synthesis. ${ }^{(65)}$ And in the RNA interference. ${ }^{(66)}$ This can be assumed as follow, the human deviance translated to satellite DNA deviance which affects alternative splicing thus changing of the produced proteins sequence and function, this cell can be described as altered cell which need to be encountered by immune cells.

Satellite DNA is divided into several categories according to size, structure and localization, According to the size of an individual repeat, satellite DNA can be divided into four classes: (1) microsatellites (less than 10 bp per repeat), (2) minisatellites (10-60 bp per repeat), (3) satellites (up to hundreds of bp per repeat) and (4) macrosatellites (several kb per repeat). To avoid potential confusion, we propose naming the third class of satellite repeats as midisatellites, leaving the term of «satellite DNA» to encompass all tandemly repeated DNA. ${ }^{(4)}$

The microsatellites are frequently involved in neuro-degenerative diseases caused by the strong expansion of Simple sequence repeat (SSR) in one gene. ${ }^{(67)}$ One of their main characteristics is a high rate of instability manifested in a loss or gain of repeat units. ${ }^{(68)}$ Other works reported that Microsatellites are codominant in nature, highly polymorphic, easily typed, and Mendelian inherited. ${ }^{(69)}$

The class of minisatellite tandem DNA contains the hypermutable repeats, which are flanked by DSB (double-strand break) hot spots and show a high rate of meiotic instability. Because of their length polymorphism, the minisatellites are used for DNA fingerprinting in forensic science for the identification of individuals by their respective DNA profiles. In addition, they have been proposed to serve as markers for genotoxicity. ${ }^{(70)}$ This characteristic make the satellite-DNA is representative for an individual like the national ID also, and this is very useful in inherited disease causality, which may reflect the behavior of a specific individual, side by side to the other satellite regions that may be more specific to reflect the ancestor behavior.

Very little is known about the midisatellite non-coding DNA, which is mostly located in the telomeric or centromeric regions of chromosomes, it play a crucial role in the chromosome segregation of normal and human artificial chromosomes (HACs). ${ }^{(70)}$ It has been proposed that the primary role of the $\gamma$-mid satellite DNA is to prevent the pericentromeric genes from epigenetic silencing. ${ }^{(71)}$ When genes are silenced, their expression is reduced. ${ }^{72)}$

The macrosatellite repeat (MSR) DNA is the only satellite DNA that could contain an open reading frame (ORF) and thus, could produce protein-coding RNA in every repeat unit. ${ }^{(73)}$ Thus it has the potential to be translated and affecting on other coding genes.

The role of MSR is not well known, D4Z4 is probably one of the most studied macrosatellites because of its association with facioscapulohumeral muscular dystrophy (FSHD). ${ }^{(74)}$

In recent years, much attention has been brought to the role of repeat sequences in various pathologies, such as epilepsy, embryonic lethality 
and cancers. ${ }^{(75-76)}$ The increase in the number of copies of repeats in genomic DNA is the single most important cause of nearly 30 hereditary disorders. Most of these diseases are due to the microsatellites, whose structural features often result in the disruption of DNA replication, repair and recombination processes, leading to expanded or contracted DNA structures. ${ }^{(77)}$ The microsatellite expansion diseases can result in a gain or/and loss of function. Among disorders caused by gain-of-function mechanism, the main cause is the protein conformation alteration, leading to changes in protein activity or abundance. ${ }^{(78)}$

Intriguingly, for the microsatellite expansion related pathologies, a correlation has been reported between the size of the repeat tandem and the severity of the disease. ${ }^{(79)}$ This correlation is behind the phenomenon of genetic anticipation, according to which the progressive increase in the repeat number (to be inherited in subsequent generations) results in the increased severity and earlier manifestation of disease. (80) this clue explain why the prevalence of a disease increase with time within a population, as the social acceptance to a deviated behavior from someone proposed to duplicate the repeat of the satellite DNA in the subsequent generation whose repeat the deviated interactions and so on, and thus increase the incidence and the severity of this disease which be assumed to be related to specific behavioral deviation.

Rich Jand et al, claimed that the exact molecular mechanisms of how satellite DNA can be involved in pathology remain largely unexplored, particularly when satellite DNA is not located in the coding region of the affected gene. ${ }^{(4)}$

In the other hand, the novel insight of this work have turned out to be a rosetta stone for unlocking the mysteries of disease susceptibility when it connects between the human deviated behavior and his Satellite DNA causing a disease where this deviation translated to pathologically genetic repeat or inappropriate transcription of RNA either quantitatively (amount of a protein) or qualitatively (function of proteins).

In addition, «Breaking of satellites' silence» is now a new paradigm in cancerogenesis. ${ }^{(81)}$ While gene-specific loci can be either hypo or hyper- methylated in cancer, the highly repeated DNA sequences are only hypomethylated in this disease. Moreover, the global DNA hypomethylation observed so frequently in cancers is mostly due to satellite DNA. ${ }^{(82)}$

Satellite DNA hypomethylation has been postulated as the mechanism that underlies the induction of peri-centromeric instability in many

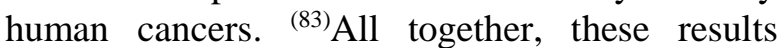
suggest satellite repeats to be the main target for hypomethylation. ${ }^{(4)}$

There was no data in the literature concerning the potential mechanisms for the selective demethylation of satellite DNA in cancer. Nevertheless, this phenomenon and the overexpression of satellite transcripts in this disease could potentially be useful as a biomarker for cancer detection and for the evaluation of the efficacy of anti-cancer treatment. ${ }^{(4)}$

Although there is no data in the literature concerning the potential mechanisms for the selective demethylation of satellite DNA in cancer, the suggested theory assume the mechanism by which we can understand the cause of selective methylation, as every disease has a specific change in satellite DNA is a translation of a corresponding deviated behavior. This will be confirmed in the evidence part, and this hypothesis will be studied later. In addition, if this hypothesis accepted, it will be recommended understanding the language of satellite DNA through detecting the specific pattern of repeats for all the corresponding disorders.

It is now self-evident that satellite DNA characteristics can be matched the human behavior characteristics. the theory that says that the deviation in human behavior is translated in the satellite DNA as harmful mutable changes causing increase the susceptibility to diseases, can be seen as plausible theory, especially when recalling the previous information that emphasizes that Satellite DNA is guilt by causation for many inherited diseases.

The answers of the fourth question which says: if the deviated behavior cause DNA change in a specific region, which type or region of DNA that may reflect this deviation? Is assumed strongly to be the "Satellite DNA" 


\section{Susceptibility controversy; approach to solve}

The risk of developing IDDM if you are the identical cotwin of an IDDM patient is about 36\%.

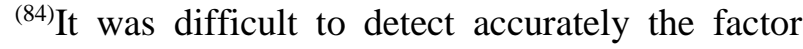
that makes someone is affected by hereditary diseases while another prone person is not.

It has been reported that Diseases included IDDM, RA, systemic Lupus Erythematosus (SLE), Multiple Sclerosis (MS) and Myasthenia. Striking differences in concordance rates between identical and non-identical twins in all these studies suggest that genetic factors are important in causing these diseases. All the diseases are known to be associated with HLA genes on chromosome 6 which may account for some or all of the genetic susceptibility (the previously illustrated HLA loci). However, in the majority of pairs the affected twin has an unaffected cotwin, these observations suggest that non-genetically determined factors are critical ${ }^{(85)}$ this non-genetically factor must be the behavior. Although the twins may share the same HLA and satellite DNA repeats, the disease does not appear to them together, this seems to be controversial!

\section{Genetic damage and genetic repair}

The behavioral deviance is suggested in this article to be pivotal non-genetically determining factor, in addition, the ideal behavior is assumed to be as an activator for the genetic repair, and thus the disease can't appear. But how to draw the behavior effector mechanisms to explain the susceptibility controversial phenomenon?

At first, it is important to recall some genetically concepts like genetic repair and genetic anticipation.

Every day, thousands of DNA damaging events take place in each cell of our body, but efficient DNA repair systems have evolved to prevent that, it can be assumed that these epigenetic inactivation processes can result in an increase in genetic instability during tumorigenesis that can be directly attributed to the deficiencies in DNA repair. ${ }^{(86)}$

DNA damage has been long recognized as causal factor for cancer development. When erroneous DNA repair leads to mutations or chromosomal aberrations affecting oncogenes and tumor suppressor genes, cells undergo malignant transformation resulting in cancerous growth.
Genetic defects can predispose to cancer: mutations in distinct DNA repair systems elevate the susceptibility to various cancer types. ${ }^{(87)}$

The previous data revealed that the genetic repair mechanisms is an opposite of the genetic damage mechanisms, the question is: what are the factors that make one mechanism is more dominant than the opposite mechanism? If it accepted that the genetic damage is a result of deviated behavior, the genetic repair can be assumed to be a result of refusing the deviated behavior.

Genetic anticipation, what is the relation?" Anticipation" is the term given to the apparent occurrence of an inherited disorder with progressively earlier age at onset in successive generations. It has been discussed in relation to many different disorders, principally those showing autosomal dominant inheritance and variable expression. ${ }^{(79)}$

Genetic anticipation can be seen as a result of repeating a deviated behavior, which causes pathological increasing in satellite DNA repeats. The generations strongly accept the inherited deviated behavior from their ancestors.

The interaction between these factors-genetic damage and genetic repair-yield a net result regarding susceptibility to specific hereditary disease and explain why the twins can show different susceptibilities although they share the same genetic material, one twine accept the deviated behavior and thus increases the genetic destruction and reduces genetic repair that cause the disease appearance, the cotwin refuses the deviated behavior or travelled to a community refuse this deviated behavior, this activates the genetic repair for the previously inherited and damaged satellite genes. It seems to be plausible explanation!

\section{Hypothesized aspects of inheritance}

if the ancestor of a family has a vigorous deviated behavior, I suppose that this behavior is translated in the satellite DNA, as previously illustrated, this Satellite DNA will cause specific genetic change in the coding region through RNA or through a corresponding mechanism, the disease isn't predicted to appear immediately, this alteration in 
the coding region may appear in late ages and thus it is possible to not be noticed, the disease will appear in gradual intensity through the successive generation (genetic anticipation), this may explain why there is appearance of new diseases which weren't known before to the ancestor.

It is predicted that the only change that transfer to fetus through sperm or ova is the change of satellite DNA, which reflects the susceptibility. Note that it is proposed that the fetus coding DNA has no alteration, the alteration later will appear as a result of the altered satellite DNA accumulating signaling. The disease will appear in the further generations according to: how many repeats in the satellite DNA are created or changed and the time needed for the satellite signals to cause specific genetic damage, and to what extent RNA affected, to what extent coding DNA is altered, to what extent the genetic repair resist.

To differentiate between a three conditions, it will be hypothesized that this ancestor has three sons, the three sons equally has the probability to have a mutated gene. This mutation appeared to be caused by the progressive intergenerational expansion of a simple DNA repeat in satellite DNA, but the three sons has different response toward this deviated behavior as follow:

1- The first son accept and share this deviated behavior, thus he is more prone to further expansion in the simple DNA repeat, with less active genetic repair, thus increased severity and earlier manifestation of the corresponding disease, the penetrance of mutations responsible for these diseases also appeared to increase in successive generations, this seems to be an accepted explanation to the phenomenon of genetic anticipation.

2- The second son, didn't accept and didn't refuse, he less prone than the first, but still carrying the deviated satellite repeats, thus still susceptible to the corresponding disease and may show manifestation later than the first one.

3- The third didn't accept this deviated behavior, this activates the DNA repair system which resist the effect of altered satellite DNA, thus less susceptibility to diseases and he is likely to be more immunized to this corresponding disease, although he shares the same disease-related HLA and satellite DNA.

This hypothesized aspects of inheritance seems to be explanatory to the previous controversial phenomenon in plausible demonstration according to previously well-known data.

\section{Hiatus for New infectious diseases}

Appearing of New infectious agents which weren't previously known is a pivotal problem added to the problem of endemic diseases within a community, I suppose that the inappropriate RNA messages that produced from non-coding DNA reduce the efficiency of the immune response thus entrance of a microbe which wasn't has pathological behavior before.

The MHC polymorphism reduce the susceptibility: Some evidence suggests that a reduction in MHC polymorphism within a species may predispose that species to infectious disease. In one example, cheetahs and certain other wild cats, such as Florida panthers that have been shown to be highly susceptible to viral disease also have very limited MHC polymorphism. It is postulated that the present cheetah population arose from a limited breeding population, or genetic bottleneck, causing a loss of MHC diversity. This increased susceptibility of cheetahs to various viruses may result from a reduction in the number of different MHC molecules available to the species as a whole and a corresponding limitation on the range of processed antigens with which these MHC molecules can interact. As a corollary, this suggests that the high level of MHC polymorphism that has been observed in many outbred species, including humans, may provide a survival advantage by supplying a broad range of MHC molecules and thus a broad range of presentable antigens. ${ }^{(88)}$

Although human has MHC polymorphism, some communities show higher susceptibility to infectious diseases than the neighboring communities, the new insight provoke the suggestion of the deviated community which has less efficient satellite DNA signaling causing opening a new pathological hiatuses, this hiatuses will be route of pathogens which was considered weak and thus this community will be more prone to specific epidemic disease corresponding to the new opining hiatus, this hiatus will be found in the whole community which accepts and legalize a deviated behavior or has unsolved bad humanhuman interaction, this explains why epidemic diseases is very related to some communities than others. It's supposed that the community with behavioral deviance is more prone to be affected by immunodeficiency syndromes than other communities that doesn't have this behavioral deviance. This must be studied. 
Obscenity; How to identify

Many tests have been used in attempts to define obscenity, but none that have really come to a socially definitive agreement. ${ }^{(89)}$ When Humanity is trying to define something, the communities differ in their definitions according to their thinker logic, knowledge and his degree of bias that range from 0 to $100 \%$, maybe there are other factors, therefore, the definitions differ in the distance to reality and have dissimilar accuracy. I suggest a fascinating note regarding the real definitions "the accurate definitions of all things in all sciences in our earth must converge and fit together without any conflicting or controversy"!

\section{The moral relativism controversy}

The Community-Human theory has been instructed to solve some relativity problems regarding the medical and social perspective. Relativism is the idea that views are relative to differences in perception and consideration. There is no universal, objective truth according to relativism; rather each point of view has its own truth. ${ }^{(90)}$ The term of moral relativism is often used in the context of moral principles, where principles and ethics are regarded as applicable in only limited context. There are many forms of relativism which vary in their degree of controversy. The term often refers to truth relativism, which is the doctrine that there are no absolute truths, i.e., that truth is always relative to some particular frame of reference, such as a language or a culture (cultural relativism). ${ }^{(91)}$

It s important to find a standard definition of the behavioral deviation. Although the universe has differentiated cultures, but clinically we share the same medical laws regarding our bodies. Therefore, the new definition that we shall accept must agree with the new insight. This way will help identify the truth and the golden mean regarding human-human interaction in simple way.

At first, Deviated behavior (obscenity) or failed human-human interaction are now considered two faces of one coin, a priori, the deviation not about only sexual deviation, but include all crimes regarding the environment, money, mind and souls. The deviated behavior need to be defined in order to avoid it, as a try to prevent satellite DNA deterioration and activating the genetic repair, thus limiting disease susceptibility in low cost strategy.

\section{The right definition of obscenity}

"What is "obscene" under U.S. law has plagued our courts for the last fifty years. It is surprising how recently the difficulty in definition of obscenity "said Judith Silver Esq. ${ }^{(92)}$

Interestingly, the definition of obscenity that fit to our new insight is found in the Arabic dictionary. Which simply define the obscenity as "Any act which exceeded the allowable limit"! (28)This definition supports the new insight where regarding human body, any markedly increased or decreased value of biological marker from the reference range considered a pathological condition and called abnormality, this is for cellcell interactions, in the social human-human interaction will called obscenity.

Relation between certain disease susceptibility and type of obscenity has been proposed, it's predicted that certain types of tumor that spreads more frequently in a community reflects a certain type of obscenity in this community. As illustrated above, and simply, as cell-cell interaction has a reference range, the human-human interaction must have a range or limits. Breaching the allowable limits of interaction is called "obscenity" which compulsory will cause increased susceptibility to disease.

A Priori, the more we move away from the golden mean of interaction, the greater the susceptibility increasing, and thus, the greater the severity of obscenity, the greater the likelihood of vigorous gene breakage and mutation, giving the opportunity to weak biological agent to enter the body pathologically, thus appearing of new infectious diseases wasn't found in the community ancestors. In addition, increase of unknown or rare cancers, which be inherited through satellite DNA repeats to the subsequent generations. Illustrative evidence will be derived later.

\section{How can human-human interaction and}

\section{obscenity identified?}

What a society considers to be a natural interaction, by contrast, another society sees as obscene. Therefore, there is a need to know the means of assessment, as it has proved the importance of erasing the obscene acts to ensure the safety of society.

\section{Non-altered satellite DNA reflect the common} sense: The first way to detect an obscene interaction is through "common sense" which crystallized in what Justice Potter Stewart said "I shall not today attempt further to define the 
kinds of material I understand to be embraced. But I know it when I see it" ${ }^{\prime(93)}$

This preconceived knowledge of obscenity comes through original common sense, which, if it was a healthy instinct, it will be able to define obscenity with all precision. Because the satellite DNA basically predicted to be an expression of common sense. If altered it will see the obscene interaction as a normal interactions.

If supposed that the common sense is a translation to the satellite DNA in a community, the inherited deviated satellite will cause a distortion in the eye of common sense. Thus, the obscenity may be seen as a normal interaction in this community (moral relativism). It is a dilemma!

The prevalence as a social marker: The solution to these communities is to look at neighboring communities - which shows low prevalence of specific diseases then find the differences in laws, habits and behavior. And thus they can identify behaviors that cause increased disease susceptibility. In addition, the new insight of this article may help detecting obscenity aspects, the human body will be taken as a model for community, as will be explained later

Behavioral deviance and disease susceptibility: Supporting evidences

The study will focus in the non-communicable diseases (like cancer) which reflect the inherited genetic susceptibility, in addition, the availability of map-supported statistics regarding cancer incidence made the measurement easier in comparing communities, clearer and significant. The study will be conducted on 1- communities that deviated in their hygienic interactions to identify the major affected organ from environmental pollution and the carcinogenic products (thus neglecting their role in explanation of the other cancer causes), 2- communities that legalized Deviated behavior (homosexualpolyandry), 3- communities that failed in preventing a deviated behavior (Forced rapes), 4communities that replace cohabitation with marriage. The study will focus in comparing a community to the neighboring communities, to visualize the differences with neglecting the environmental causes as they approximately share a same environment.

\section{1-Environmental industrial pollution and}

\section{hepatocarcinoma}

The human body that has high blood level of wastes (urea, creatinine) is like community with high levels of un-managed wastes, studying a community like that may introduce a good picture about the type of genetic susceptibility affected by pollution. Recall that the liver is the organ that considered a manufacture that also plays a role in removing toxicity, therefore the deviated industrial interactions suggested being translated to an increased prevalence of liver cancer in any country that has violations in the field of industry and infringement of the environment. By other words, the unmanaged industrial operations in community will reflect as an unregulated hepatocyte-hepatocyte interactions and hepatocyte-other cells interactions in body, showing high susceptibility to liver diseases in this community. The main mediator is the accumulated wastes.

Egypt is an example of severe environmental pollution: Egypt shares most of the environmental problems of developing countries. One of the most important health and environmental problems is air pollution resulting from using fuel, burning operations, and the increase of automobile exhaust in cities. Moreover, the deficiency of efficient sanitation services and water pollution caused by the breaking down of old and consumed water networks, as well as the various problems in construction, designing and maintenance of sewage system resulted in the appearance and prevalence of communicable and non-communicable diseases. There are several examples of exposure to chemical genotoxicants, and lifestyle exposures in the population, which create unique combinations of environmental risk factors for diseases such as cancer. Environmental factors may interact with infection and lead to enhancement of carcinogenicity processes. ${ }^{(94)}$

In Egypt, Rosetta branch, one of the two main branches of the Nile River, is impacted by several industrial companies at Kafr El-Zayat City which potentially affect and deteriorate its quality of water. ${ }^{(95)}$

Egyptian liver has higher susceptibility to be diseased. Where $\mathrm{HCV}$, and its long-term resultant consequences, is a major endemic medical health problem in Egypt. Having taken a representative sample of the country, from both urban and rural areas, an Egyptian demographic health survey conducted in 2008 concluded that $14.7 \%$ of the population have been infected, making this the highest prevalence in any population in the world. ${ }^{(96)}$ 


\begin{tabular}{|c|c|c|}
\hline Community & $\begin{array}{l}\text { Total cancer } \\
\text { cases annually } \\
\text { per } 100,000 \\
\text { people in } 2008\end{array}$ & $\begin{array}{l}\text { Liver cancer } \\
\text { cases annually } \\
\text { per } 100,000 \\
\text { people in } 2008\end{array}$ \\
\hline Egypt & 108.4 & 9.3 \\
\hline Gaza strip & 54.9 & 2.0 \\
\hline Sudan & 81.5 & 3.9 \\
\hline Saudi arabia & 87.6 & 3.6 \\
\hline Libya & 111.3 & 3.4 \\
\hline Jordon & 128.9 & 1.5 \\
\hline Cyprus & 178.8 & 1.4 \\
\hline Israel & 288.3 & 2.4 \\
\hline China & 181.0 & 25.7 \\
\hline USA & 300.2 & 4.5 \\
\hline
\end{tabular}

$\mathrm{HCV}$ is a significant "precursor" for fibrosis, cirrhosis, and ultimately, hepatocellular carcinoma, but it is important to understand this is only in long-term, chronic cases. ${ }^{(97)}$ The main risk factors for transmission of HCV in Egypt historically have included the now archaic parenteral antischistosomal therapy, shared or reused needles, poorly sterilized surgical or dental equipment, and blood transfusions. ${ }^{(98)}$

Surprisingly, the incidence of liver cancer in Egyptians was more than 3 times that in US and about 5 to 7 times that in the other MECC SEER (the Middle East Cancer Consortium, which is Cyprus, Egypt, Israel, and Jordan) populations in the Period 1996-2001 (see Map 1). ${ }^{(99)}$ The question is: what makes the Egyptian liver has higher susceptibility to be diseased (especially towards infections like schistosomal invasion and hepatitis $\mathrm{C}$ virus) than the surrounding communities?

The data can lead us to say that the Egyptian susceptibility to hepatocarcinoma is raised comparing with the surrounding communities (see Table 3)-as a result of accumulating deviated hygienic human-human interactions, it is clear that the hygienic deterioration is a result of the unwise governmental decisions.

In addition, it's well-known that China is one of the world's largest manufacturers, and it has markedly high incidence of liver cancer also (see table 3), this seems to be relevant, thus I suggest revising the industrial processes in China to detect the deviated industrial interactions that led to this markedly high incidence of hepatic cancer.

I suggests linking between industrial pollution with the genetic susceptibility of the liver, but if this became accepted-that carcinogenic materials in principle affects the liver and lower the genetic repair ability leading to other cancers-what is the other deviated interaction that is a cause to the genetic deterioration leading to lung, prostate, breast, cervical cancers?

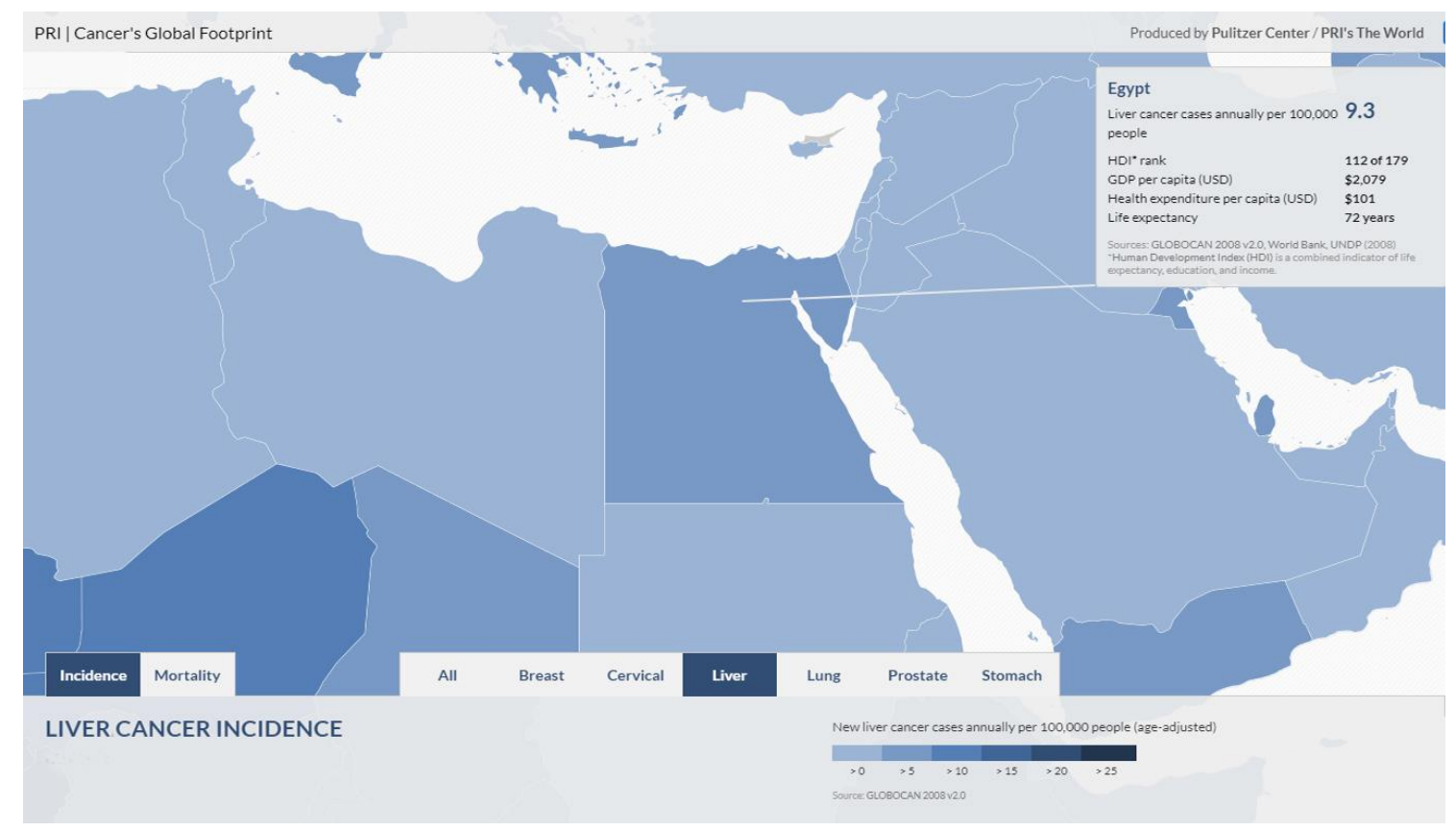

Map 1: New Liver cancer cases annually per 100,000 people in the Middle East region, the darker in color, the higher in incidence. ${ }^{(101)}$ 
2-Homosexuality legalization and increasing susceptibility to cancer (especially lung. prostate colorectal cancers)

What is the golden mean regarding sexual humanhuman interaction? And why? Having sex is an important Human-human interaction regarding reproduction, enjoyment and expression of love, the golden mean in this interaction must been between married man and women, as the three main objectives will be achieved safely. Couples will have children and will care for these children to ensure that there is no deviation in their behavior towards their community, and this deviation as I explained earlier accused of being a cause of increased susceptibility to diseases.

Couples that care about raising and disciplining their children are like development of $\mathrm{T}$ cells in the thymus as it learns how to identify self-Antigens thus don't provoke any vigorous auto-reactivity towards their body compartments. In basis of what previously illustrated, shall we suppose that community that have children born to non-married couples has increased probability of autoimmunity diseases? As these children will not be fully cared and may acquire destructive behavior towards the community similar to the autoreactive $\mathrm{T}$ cells. I assume that this destructive behavior will be translated genetically, and further Studies are recommended for testing this hypothesis.

However, if this condition happened - the relation between non married man and women that called cohabitation- it still logically accepted, although there is no complete care for the family, the three goals still achieved. Increasing the number of non-married couples can be considered in this topic as a risk factor for further complications, regarding our perspective it considered a slightly high value from the reference range. By contrast, sexual humanhuman interaction which don't lead to further generation, male-male sexual deviation and subsequently female-female sexual deviation, is considered severe obscene interaction. Why?

As illustrated above, the cells are highly designed to serve their body, in contrast the body need to have new cells rise from mitosis to compensates the aged, altered, or dead cells, the reproduction is pivotal goal, which in humans induced by the other two goals (Love " feelings " and enjoyment). In our new perspective, the last two goals can be seen as a two means that induce the first pivotal goal.
Therefore, any sexual human-human interaction that don't lead absolutely to further generation can be considered obscene interaction thus it supposed that communities that legalize this very obscene deviated interaction is more prone to has very high incidence of diseases. In cellular view, Apoptosis and proliferation are intimately coupled. Some cell cycle regulators can influence both cell division and programmed cell death. (102) which may be disturbed by in appropriate RNA signals from deviated satellite DNA. In selective manner according to type of the social deviance. This may explain the cause that makes the altered cells increases and have been ignored thus initiate a cancer.

Apoptosis is a very tightly programmed cell death with distinct biochemical and genetic pathways that play a critical role in the development and homeostasis in normal tissues (103) Defect in apoptosis can cause cancer or autoimmunity, while enhanced apoptosis may cause degenerative diseases. ${ }^{(104)}$ this processes are important to maintain cell number and efficacy, without cell proliferation the body will shrink to death!

Recall that the communities that ignore a deviated ancestor then legalize his interaction is like the human body which has immune system failed in inducing apoptosis to the altered cells, this body is more prone to cancer, similarly, this community is expected to have high incidence of cancer.

Basis on that and according to the new perspective, I assume that the community that legalized homosexuality has a causative relation to:

1- Decreased population growth rate, which if negative means community extinction

2- Increases prevalence of tumors, infectious and degenerative diseases as a result of the deeply troubled satellite DNA.

3- Increased hereditary susceptibility to specific diseases corresponding to the deviated interactions.

4- The incidence of the diseases is increasing with time, as the inherited deviated message from the multiplied repeats of satellite DNA increases with time in every successful generation (genetic anticipation). 
To test this hypothesis, the author searched for communities that encoded homosexuality where the surrounding communities didn't, to insures that this communities almost environmentally similar, and differ only in homosexuality legislation, in order to see if there a significant difference in disease susceptibility between this communities or not.

Studying the relation between homosexuality and increased cancer incidence in South Africa community: the study showed that markedly high disease incidence (especially prostate, lung and colorectal cancers).In 1996, the South African government approved a new constitution. In addition to ending de jure apartheid, it was the first in the world to protect the rights of homosexuals.

Lawmakers made history-According to the author- by writing sexual orientation into the national non-discrimination clause, enshrining gay rights in the supreme law of the land. This progressive government and constitution, however, did not reflect the attitudes of most South Africans, who did not support gay rights. The government created a gap between its tolerant laws and the conservative social attitudes of its citizens. ${ }^{(105-106)}$ In 2006, South Africa was the fifth country, the first in Africa, the first in the southern hemisphere, the first republic to safeguard sexual orientation as a human right in its Constitution. ${ }^{(106-107)}$
In 2014 reported that the growth rate of South Africa is -0.48 . A positive growth rate indicates that the population is increasing, while a negative growth rate indicates that the population is decreasing. ${ }^{(108)}$

21 years after its first -what's calleddemocratic election, South Africa is in the midst of a health transition that is characterized by the simultaneous occurrence of epidemic infectious diseases and a rise in non-communicable diseases, in a population facing a heavy burden of perinatal and maternal disorders, injury, and violence. ${ }^{(109)}$

GLOBOCAN, a project of the International Agency for Research on Cancer. The data are estimated in 2008 revealed that South Africa markedly shows the highest cancer incidence in Africa, 202 Cancer cases annually per 100,000 people, While the surrounding countries show lower incidence where Namibia 78.3, Botswana 85.7, Zimbabwe 159.1 and Mozambique 123.5 (See table 4 and Map 2). ${ }^{(100-101)}$

South Africa is the highest incidence than the other countries and shows significantly very high Incidence in prostate cancer $(59.7$ cases per 100000 people) and significantly high incidence of lung cancer (18.2 cases per 100000 people) ${ }^{(100-}$ 101) and colorectal cancer (11.9 cases per 100000 people). ${ }^{(110)}$

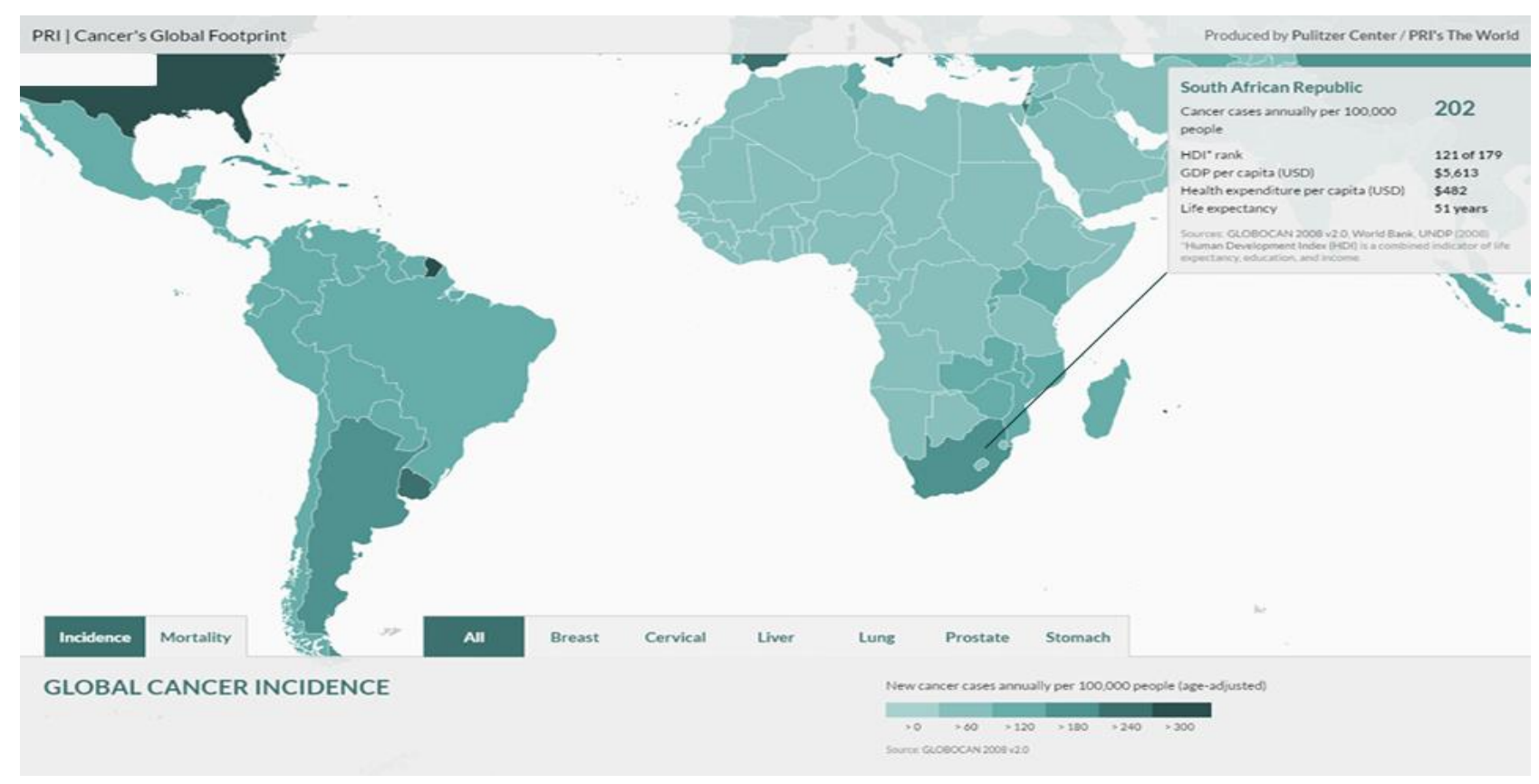

Map 2: New cancer cases annually per 100,000 people in the South Communities of Africa. Showing the markedly high incidence of cancer in South Africa community, the Darker in color, the higher in incidence. ${ }^{(101)}$ 


\begin{tabular}{|c|c|c|c|c|c|}
\hline Community & $\begin{array}{c}\text { Total } \\
\text { Incidence }^{(100)}\end{array}$ & $\begin{array}{l}\text { Prostate } \\
\text { Cancer }^{(100)}\end{array}$ & $\begin{array}{c}\text { Lung } \\
\text { Cancer }^{(100)}\end{array}$ & $\begin{array}{l}\text { Colorectal } \\
\text { Cancer }^{(112)}\end{array}$ & $\begin{array}{l}\text { Liver } \\
\text { cancer }^{(100)}\end{array}$ \\
\hline South Africa & 202 & 59.7 & 18.2 & 11.9 & 9.5 \\
\hline Namibia & 78.3 & 14.8 & 3.4 & 4.8 & 1.7 \\
\hline Botswana & 85.7 & 8.9 & 2.3 & 3.5 & 2.8 \\
\hline Zimbabwe & 159.1 & 26 & 4.1 & 8.8 & 6.9 \\
\hline Mozambique & 123.5 & 16.1 & 2.1 & 1.2 & 4.6 \\
\hline \multicolumn{6}{|l|}{ In Middle East } \\
\hline Egypt & 108.4 & 6.6 & 5.9 & 5.6 & 9.3 \\
\hline Gaza strip & 54.9 & 7.4 & 5.9 & & 2.0 \\
\hline Sudan & 81.5 & 9 & 1.8 & 4.6 & 3.9 \\
\hline Saudi Arabia & 87.6 & 7.7 & 5.2 & 11.6 & 3.6 \\
\hline Libya & 111.3 & 10.3 & 14.6 & 14.5 & 3.4 \\
\hline Jordon & 128.9 & 13.9 & 11.2 & 25.6 & 1.5 \\
\hline Cyprus & 178.8 & 46.8 & 12.7 & 24.5 & 1.4 \\
\hline Israel & 288.3 & 55.1 & 23.8 & 35.9 & 2.4 \\
\hline \multicolumn{6}{|c|}{ Different countries in worldwide. } \\
\hline Turkey & 144.8 & 14.8 & 26.0 & 16.6 & 2.5 \\
\hline China & 181.0 & 4.3 & 33.5 & 14.2 & 25.7 \\
\hline USA & 300.2 & 83.8 & 42.1 & 25.0 & 4.5 \\
\hline Canada & 296.6 & 101.5 & 35.9 & 35.2 & 3.3 \\
\hline France & 300.4 & 118.3 & 30.0 & 30.0 & 6.0 \\
\hline Denmark & 326.1 & 72.5 & 38.4 & 40.5 & 3.1 \\
\hline United Kingdom & 266.9 & 64.0 & 31.3 & 30.2 & 3.0 \\
\hline Australia & 314.1 & 105.0 & 25.6 & 38.4 & 3.5 \\
\hline Uruguay & 280.3 & 102.8 & 29.0 & 29.5 & 1.7 \\
\hline
\end{tabular}

These facts suggest the causal relation between homosexual behavior between men and prostate cancer, then lung and colorectal cancer in the two genders, this confirms the increased inherited susceptibility due to deviated interactions acceptance.

I suggest that homosexuality has direct effect to prostate cancer and indirect effect to lung and colorectal cancers where the satellite DNA play an intermediate role and the further generation receive the genetic susceptibility from the deviated satellite DNA of the deviated ancestors, although they may not undergo this deviated interaction. The altered DNA may reduce the immune response efficacy, this explains why they have less immunized body, thus high susceptibility to communicable diseases.

In addition, the inherited immunological tolerance can be genetically disturbed, As a try to explain, the female body has been created with the ability to receive the foreign antigens of a man where the male hasn't been, he don't need this ability. As Successful pregnancy requires a state of maternal immune 'tolerance' to accommodate antigens expressed by the conceptus. Implantation failure and placental pathologies largely reflect insufficiencies in maternal immune adaptation ${ }^{(111)}$, I suggest that homosexual behavior interactions may has a pathological genetic consequences regarding tolerance and inherited genetic mutations.

Although other communities may have some individual of deviated homosexual behavior. The burden of disease susceptibility will not occuraccording to the new perspective-, as the whole community refuse this behavior and continuously eliminate it. As same as elimination of cancer cell "DNA-altered cell' by the good immune system cells. Acceptance and legalize a deviated behavior is an important factor in this theory. In addition, the communities that show low percentage of prostate cancer - as example-may be a result of some deviated individuals or lowered genetic repair which affected by the accumulated environmental carcinogenic materials. Other data emphases the causal relation between prostate, lung and colorectal cancers and legalization of the homosexuality, as example, other communities that legalized homosexuality (Showed in black background in table 4), ${ }^{(108)}$ show markedly high incidence of cancer and especially prostate, lung, colorectal cancers, giving the evidence that legalized social deviance has a causative relation with disease susceptibility in a specific manner, which may be through the altered satellite DNA. And this findings strongly fulfill the hill criteria. 


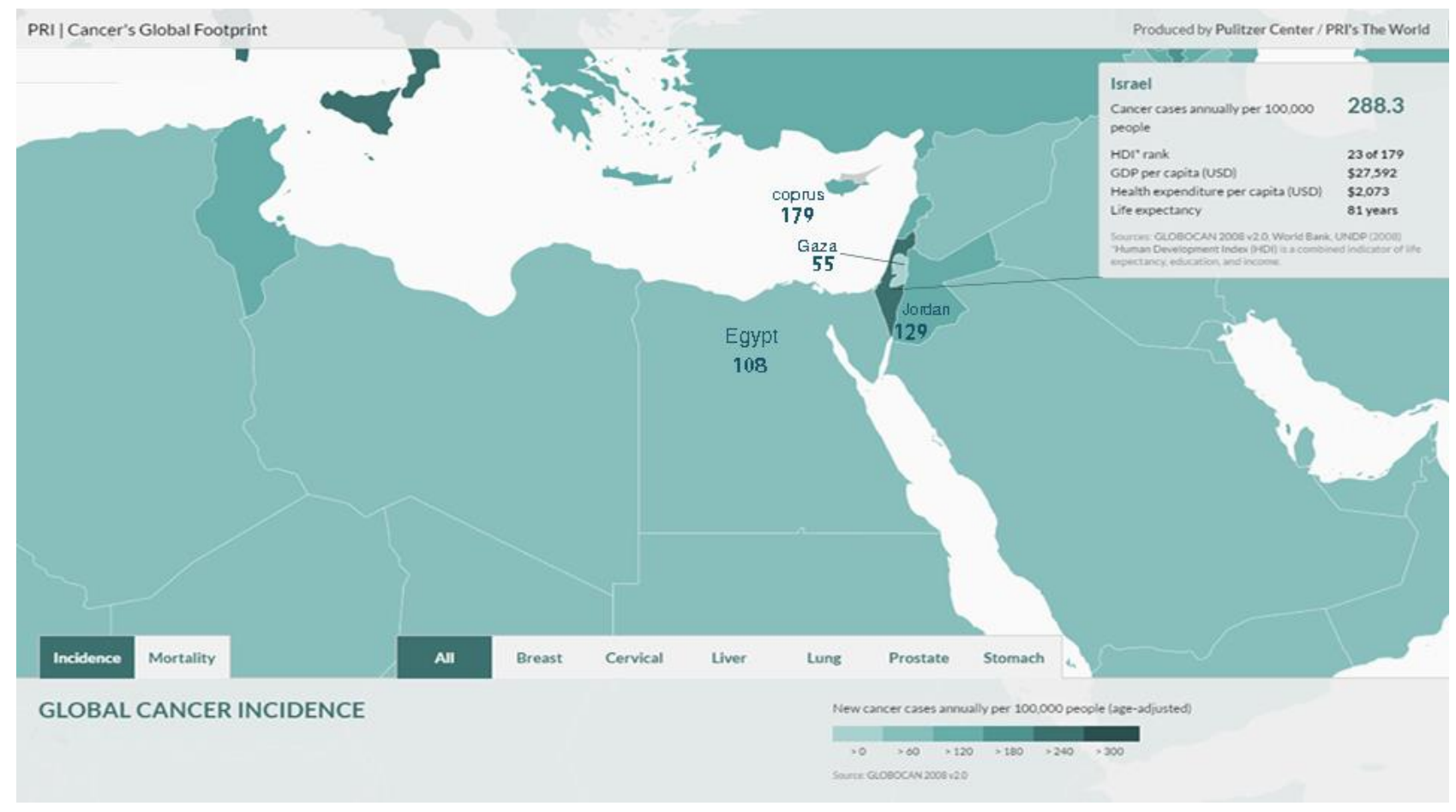

Map 3: New cancer cases annually per 100,000 people in the communities found in the Middle East. Showing the markedly High incidence of cancer in the Israeli community, the Darker in color, the Higher in incidence. ${ }^{(101)}$

\section{Studying the relation between increased} deviated interaction and cancer incidence in Israel: the study showed that the cancer incidence in Israelis much higher than the neighboring communities in the Middle East and South Africa community.

Homosexual and transgender rights in Israel are the most protected in the Middle East and one of the most advanced -According to the author- in Asia. ${ }^{(112)}$ Among Middle Eastern communities, Israeli society has not only accepted homosexuality, but has also accepted sexual transformation, Therefore, it is hypothesized that cancer susceptibility in Israel must be higher than those of south Africa (see table 4)., as Israel legalized two obscene behavior not only one (according to hill criteria "Biological gradient "), in addition, I assume that there are significantly difference in cancer incidence between Israel and the neighboring communities which didn't legalize these obscene interactions.

I found that cancer incidence of Israel (288.3 per 100,000) is higher than cancer incidence of South Africa (202 per 100,000), and the neighboring communities like Egypt (108.4 per 100,000), Gaza a $(54.9$ per 100,000) and Saudi Arabia ( 87.6 per 100,000$)$ (see map 3 and table4), (100-101) this Supports the hypothesis that the greater the acceptance of an obscene acts, the greater the inherited susceptibility to the corresponding disease. (See table 4).

In addition, Israel like South Africa community, show very high incidence of prostate Cancer (55.1 per 100,000), lung Cancer (23.8 per 100,000) and colorectal Cancer (35.9 per $100,000)$ compared to the neighboring communities (see table 4), ${ }^{(100)}$ This confirm the specificity of the deviated human interaction to cause certain cancers, these results regarding the deviation as a cause and increased susceptibility as an effect, fulfil the Hill's criteria in strength of association, consistency (replication by other laboratories or other cross sectional studies), specificity (the deviated behavior has a corresponding disease), temporality (whether exposure preceded disease), biologic dose gradient(the more acceptance lead to more susceptibility), plausibility (credible scientific explanation), coherence with other evidence, experimental evidence, and analogy.

Surprisingly, Gaza is the lowest incidence, although it is the nearest community (similar environmental condition) to thevery high incidence community "Israel". This weaken the suggestion of the environment has an exclusive main causal relation to caner, and this finding has another social perspective. 


\begin{tabular}{|c|c|c|c|c|c|c|c|}
\hline \multicolumn{8}{|c|}{$\begin{array}{l}\text { Table 5: Comparison betweer } \\
\text { incidence in US States. }\end{array}$} \\
\hline \multicolumn{8}{|c|}{ The most Dangerous states in USA } \\
\hline & State Name & Total Crimes & $\begin{array}{l}\text { Violent } \\
\text { crimes }\end{array}$ & murders & $\begin{array}{l}\text { Forcible } \\
\text { rapes }\end{array}$ & $\begin{array}{l}\text { Incidence of } \\
\text { breast cancer } \\
\text { in all ethnic } \\
\text { groups }\end{array}$ & $\begin{array}{l}\text { Incidence in non- } \\
\text { Hispanic Black }\end{array}$ \\
\hline 1 & Alaska & 1293 & 750 & 34 & 509 & 110 & 142 \\
\hline 2 & New Mexico & 1816 & 597 & 125 & 1094 & 95 & 107 \\
\hline 3 & Nevada & 1833 & 591 & 163 & 1079 & 95 & 110 \\
\hline 4 & Tennessee & 3050 & 580 & 328 & 2142 & 100 & 126 \\
\hline 5 & Louisiana & 2570 & 510 & 498 & 1562 & 98 & 130 \\
\hline 6 & South Carolina & 2553 & 494 & 297 & 1762 & 107 & 125 \\
\hline 7 & Delaware & 918 & 479 & 39 & 400 & 112 & 128 \\
\hline 8 & Maryland & 2027 & 468 & 381 & 1178 & 109 & 130 \\
\hline 9 & Florida & 7907 & 460 & 972 & 6475 & 98 & 110 \\
\hline 10 & Arkansas & 1913 & 446 & 159 & 1308 & 91 & 106 \\
\hline Mean & & 2588 & 537 & 300 & 1751 & 101 & 121 \\
\hline \multicolumn{8}{|c|}{ The Safest states in USA } \\
\hline 1 & Vermont & 1309 & 1149 & 10 & 150 & 47 & Less than 25 \\
\hline 2 & Maine & 485 & 122 & 24 & 339 & 63 & Less than 25 \\
\hline 3 & Virginia & 2296 & 188 & 316 & 1792 & 103 & 130 \\
\hline 4 & Wyoming & 355 & 198 & 17 & 140 & 80 & Less than 25 \\
\hline 5 & Kentucky & 1663 & 199 & 167 & 1297 & 94 & 133 \\
\hline 6 & New Hampshire & 566 & 200 & 22 & 344 & 82 & Less than 25 \\
\hline 7 & Idaho & 819 & 205 & 27 & 587 & 76 & Less than 25 \\
\hline 8 & Utah & 1127 & 209 & 49 & 869 & 102 & 109 \\
\hline 9 & Minnesota & 1982 & 223 & 114 & 1645 & 100 & 94 \\
\hline 10 & Hawaii & 617 & 240 & 22 & 355 & 131 & 134 \\
\hline Mean & & 1122 & 293 & 76 & 752 & 88 & Less than 70 \\
\hline
\end{tabular}

3-Female insecurity and breast Cancer

\section{incidence: causal Relation}

Breast cancer is the second most common cancer in the world and, by far the most frequent cancer among women with an estimated 1.67 million new cancer cases diagnosed in 2012. Incidence rates vary nearly fourfold across the world regions, with rates ranging from 27 per 100,000 in Middle Africa and Eastern Asia to 96 in Western Europe. ${ }^{(113)}$

Excluding cancers of the skin, breast cancer is the most common cancer among US women, accounting for $29 \%$ of newly diagnosed cancers. The median age of diagnosis is younger for black women (58) than white women (62), black women have a higher incidence rate before age 45 and are more likely to die from breast cancer at every age.Incidence and death rates for breast cancer are lower among women of other racial and ethnic groups than among non-Hispanic white and black women. Asian/Pacific Islander (API) women have the lowest incidence and death rates. ${ }^{(114)}$ this data reveal that the black women are more affected of a bad behavioral interaction than white women.

In a research studied Breast cancer incidence and death rates per 100,000 women by state for non-Hispanic white, black, Hispanic, and API women. Breast cancer incidence rates range from 107.7 (cases per 100,000 women) in Arkansas to 164.4 in the District of Columbia among white women; 94.0 in Minnesota to 141.7 in Alaska among black women; 44.3 in Mississippi to 134.5 in Montana among Hispanic women; and 43.0 in Mississippi to 125.0 in Hawaii among API women. Incidence rates reflect disease occurrence, as well as how completely the population is routinely screened. ${ }^{(114)}$ 
It was suggested that many factors known to increase the risk of breast cancer are not modifiable, such as age, family history, early menarche, and late menopause. Factors that are modifiable include postmenopausal obesity, use of combined estrogen and progestin menopausal hormones, alcohol consumption, and breastfeeding. Many breast cancer risk factors affect lifetime exposure of breast tissue to hormones (early menarche, late menopause, obesity, and hormone use). Hormones are thought to influence breast cancer risk by increasing cell proliferation, thereby increasing the likelihood of DNA damage, as well as promoting cancer growth. Breast cancer risk accumulates throughout a woman's life ${ }^{(115)}$

About the relation between the insecure interactions and breast cancer, there is no study connected between safety in a community and breast cancer incidence through a cross sectional study, this notion raised as a result of the new insight, the next example will try to look at the community as a human destroying his body!

The woman is much weaker and attractive than man, the safety is an important issue for any women which is supported individually by a man protective behavior and socially by the successive protective laws, any failure in this protection will be companied with a dangerous regarding the women and thus may reflect to its DNA as a message "I hope I wasn't a women", these messages are suggested be targeted to a symbol of her femininity and motherhood.

This knowledge provoke the question of: is the community that failed in preventing a deviated human-human interaction (Violence) has higher incidence of breast cancer? To test this hypothesis I select a community that is routinely screened, and comparing the safety level in the states of this community to their breast cancer incidence.

Studying the relation between insecurity and breast cancer in USA: US states 2015: How safe?, is a name of FBI report which keeps track of major violet crime in four categories: murder, aggravated assault, robbery, and forcible rape. They have identified the most dangerous states and the safest states (See table 5). ${ }^{(116)}$

The comparing between breast cancer incidence in US states -in all ethnic groups and especially in non-hispanic black women- and incidence of crimes ( see table 5), To see if there is a relation between non-safe human-human interaction and breast cancer incidence revealed that:
1- All the states that classified as dangerous has high prevalence of breast cancer.

2- The states that classified as safe show significant low incidence of breast cancer as a total and especially in 5 states (Vermont, Maine, New Hampshire, Wyoming and Idaho).

3- The states that classified as safe, but has high incidence of forcible rapes show markedly increase in breast cancer incidence (Virginia, Kentucky, Utah and Minnesota), reflecting the fact of women insecurity is a cause of breast cancer burden.

4- Only two states that lack to the proposed correlation, Florida has an extreme value of forcible rapes (6475) which seen to be a clerical error, and Hawaii which has low forcible rapes and high breast cancer incidence which seems to be defect in enrollment and statistics in this state. However, this preliminary significant study must be followed by a more detailed study.

This preliminary study shows obviously that there is a relation between women insecurity (represented in USA states in forcible rapes) and breast cancer incidence, giving the evidence that behavioral deviation in community will be translated to disease susceptibility. In addition, the community that fails in solving problems (like forced rapes) are more prone to be diseased.

Note that, the insecurity concept may occur in different ways and differ according to community, the net result of these ways is suggested to be crystalized in the form of (insecurity), this must restudied in different topics, to differentiate between the ways that leads to insecurity. Now, the main cause of breast cancer seems to be a social cause (insecurity) rather than only personal fault or predisposing to a risk factors.

\section{4-Polyandry and cervical cancer}

I took a look in communities that show high incidence of cervical cancer, and comparing this communities to other communities that has markedly low incidence I found that the communities of high cervical cancer incidence share in the legalization of polyandry!

What is polyandry and where? According to Cassidy and Lee (1989), polyandry is the simultaneous marriage of one woman to two or more men. Marriage can take many forms, and 
depending on how it is defined, can determine whether a society is actually polyandrous or not. ${ }^{(117)}$ Polyandry challenges both traditional sociocultural and evolutionary understandings of marriage. Its existence calls into question the importance of female sexual exclusivity and reproduction in marriage, two fundamental aspects of the affinal bond in most other marital forms. ${ }^{(118)}$

Polyandry was traditionally practiced among Tibetans in Nepal, parts of China and part of northern India, ${ }^{(119)}$ this behavior has been founded mainly in a tribes which may be distributed in two or more countries in varying proportions. Some communities that contain polyandries include Nepal (119), India (120), Tanzania "Pimbwe" (121), Kenya (122), Venezuela "Bari" (123), Nigeria and guinea ${ }^{(124)}$.Polyandry, a female having many husbands, is strictly forbidden in Islamic communities. ${ }^{(125)}$

Table 5: Cervical cancer incidence comparison between countries that has polyandries (in grey background) and countries that haven't polyandries (in white background)

\begin{tabular}{|l|c|}
\hline Country & $\begin{array}{l}\text { Cervical cancer } \\
\text { incidence per } \\
100,0000^{(126)}\end{array}$ \\
\hline Nepal & 19.0 \\
\hline India & 22.0 \\
\hline Tanzania & 54.0 \\
\hline Kenya & 40.1 \\
\hline Nigeria & 32.8 \\
\hline guinea & 38.4 \\
\hline Venezuela & 32.8 \\
\hline West Bank and Gaza Strip & 2.0 \\
\hline Egypt & 2.3 \\
\hline Syrian Arab Republic & 2.6 \\
\hline Saudi Arabia & 2.7 \\
\hline Iraq & 2.8 \\
\hline Yemen & 3.1 \\
\hline Sudan & 7.9 \\
\hline Libya & 9.7 \\
\hline
\end{tabular}

Studying the relation between polyandry and cervical cancers: I compared the cervical cancer incidence between countries that has polyandry and some Islamic countries in which polyandry is illegal and unaccepted, I found that there are a significant difference (see table 6), this finding confirm that the community which accept that the women have more than one hasped in one time is more susceptible to have high incidence of cervical cancer.
Therefore polyandry can be described as deviated human-human interaction. This give a clear evidence that many disorders is more related to social deviance than the suggested risk factors by many authors. I claim that this correlation must be named strong causal relation. This deviation mostly fulfill Bradford Hill criteria, the measurement can be done easily with some modifications.

\section{5-Cohabitation and Autoimmune diseases}

To what extent the plausibility of this insight? Previously, I proposed that community that has children born to non-married couples has increased probability of autoimmunity diseases. If the testing of this hypothesis significantly confirm that there is a relation between cohabitation "incomplete care of children" and autoimmune diseases increased prevalence, this will supports the strength of our novel insight, by which we can connect between two related variants which too far from each other, in addition it confirms that the cells behavior in human body and the humans behavior in community, are tightly connected!

What is cohabitation, and its effect? In recent decades, cohabitation has become a central part of the family landscape in the United States-so much so that by age 12,40 percent of American children will have spent at least part of their lives in a cohabiting household. (127) although some cohabiting parent families feature two biological parents, the most common arrangement is a biological mother and a stepfather. Despite the parallel family structure in married and cohabiting parent families, children in cohabiting parent families may not receive the same social and institutional supports that children in married parent families receive. (128) For example, cohabiting parent families don't have the same legal protections that married parent families have. Further, cohabiting stepparent families must navigate the challenges presented both by life as a stepfamily and by the lack a formally recognized relationship. ${ }^{(129)} \mathrm{A}$ key distinction appears to be among stepfathers: cohabiting stepfathers spend less time actively engaged with young children then do married stepfathers. ${ }^{(130)}$

Most importantly, cohabitation is often a marker of family instability, and family instability is strongly associated with poorer outcomes for children. Children born to cohabiting parents see their parents break up more often than do children born to married parents. In this way, being born into a cohabiting family sets the stage for later instability, 
and children who are born to cohabiting parents appear to experience enduring deficits of psychosocial wellbeing. ${ }^{(131)}$ Children born to cohabiting parents have more problems with peers, more aggressive behaviors, more internalizing problems, and more negative teacher assessments than do children born to married parents. Instability, then, appears to harm psychosocial wellbeing. ${ }^{(132)}$ is this instability will be translated to autoimmune disease susceptibility in the communities that accept cohabitation (less social care)?

Testing the relation between the cohabitation and autoimmune diseases: I conduct a rapid study to detect the relation if any between communities that accept cohabitation and its prevalence of autoimmune diseases.

A research studied the cohabitation in 28 countries where it has become a norm during the last decades, these countries with high, medium and low cohabitation rates. Some communities that have higher prevalence of cohabitation include Denmark, Norway, Netherlands, Finland, Sweden, and France, other communities that have medium prevalence of cohabitation are like New Zealand and USA, and finally Israel and Poland are an examples of countries that have low prevalence of cohabitation. ${ }^{(133)}$

Interestingly, it has been reported that, despite considerable variations between the countries, celiac, type 1 diabetes and myasthenia gravis frequencies increased the most in Canada, Israel and Denmark, respectively. Rheumatic, endocrinological and gastrointestinal autoimmune diseases in Israel, Netherlands, USA and Sweden increased the most. ${ }^{(134)}$

It became clear now that the communities that accept cohabitation show markedly increase in autoimmune disease incidence, this preliminary study results confirm that there is a relation (mainly causation) between the instable community and the inherited instable immunity. This evidence strongly support the novel insight hypotheses and plausibility. in addition, this may explains why females is more prone to autoimmune disease than males, as they more affected by the familial instability than male due to their emotional nature.

Finally, this findings clearly answered the previously driven fifth question, which says: is there any evidence that any type of failed humanhuman interaction (behavioral deviation) lead to corresponding disease? The answer is "yes".

\section{Discussion and recommendation}

The new insight and their satellite theories produce a good thinking way and a novel perspective for detecting the main causes, mechanisms, and ways of protection and treatment, in very low cost strategies. The final derived picture of susceptibility which drawn by the previous searching and testing in the light of the novel qualitative epidemiological perspective, is related to two opposite mechanisms, the first is the genetic repair while the second is the genetic damage. The disease appearance (susceptibility) is depending on which of these two mechanisms is dominant or has the upper hand (see figure 1).

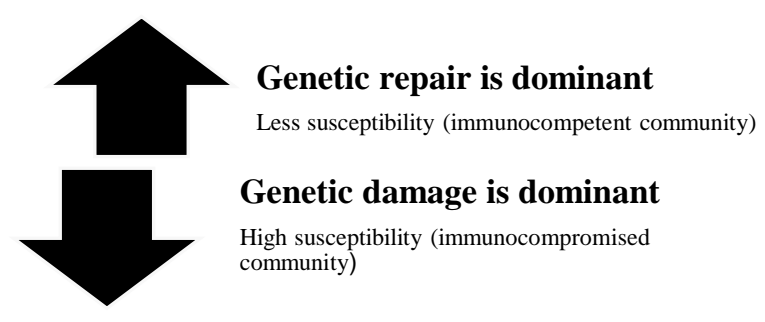

Figure 1: Genetic factors affecting susceptibility.

However, the DNA balance (Social healthy state) which occurred as a result of the two opposite operations (Genetic damage followed by genetic repair) is controlled by four opposite causes, this sequential and graduated study in this topic revealed that the genetic damage will be dominant due to two causes (The legalized behavioral deviance and exposure to the accumulated carcinogenic loads), and the legalized behavioral deviance (The obscene /failed humanhuman interactions) is more destructive than the other factor (The exposure to the accumulated carcinogenic loads), these two factors will cause a disease if increased to a level higher than the genetic repair capacity. The genetic repair capacity increased as a response to the two opposite good causes (The eliminating of the deviated interactions and/or the carcinogenic materials). Therefore, the behavioral deviance is considered the main cause regarding increased selective disease susceptibility within communities (See figure 2).

The article provides a keys for detecting causes for diseases outbreak, through connecting between human body and community. Gradually, this 
perspective led us to understand the complex body by looking at the society and by drawing legislation for society from the healthy body. One of the most important psychological conclusions is that human-human interaction must have a range (This conclusion will be beneficial to those people who believe that there is no limit to the freedom of an individual, and thus this absolute freedom will lead to the destruction of society through their genetics, whether intentionally or unintentionally), this range is assumed to be highly connected to our genes, especially satellite DNA repeats which essential reflects the common sense, and which can be distorted as a response to the deviated humanhuman interactions, thus increase inherited susceptibility to diseases, either known or unknown.

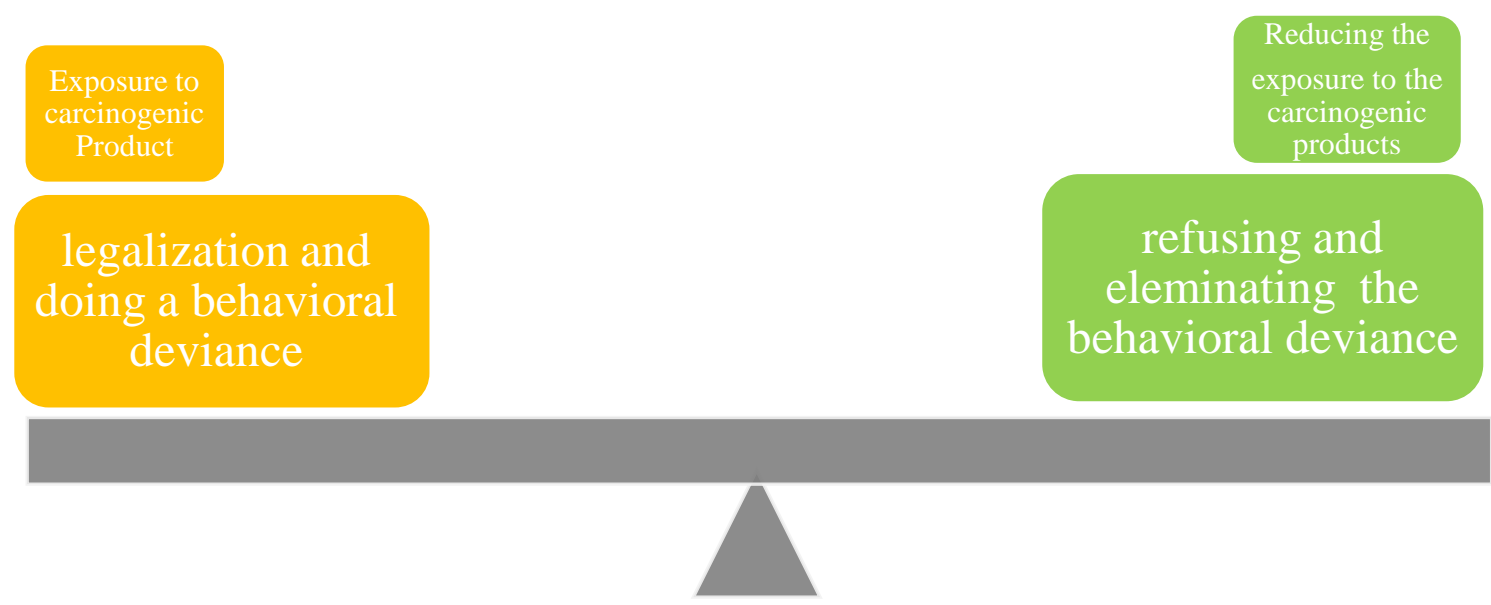

Figure 2: Factors controlling genetic repair/damage.

In addition, the novel notion of presence of certain satellite DNA patterns specific for each disease susceptibility has been assumed, this pattern formed mainly as a result of a deviated interactions, in addition, I assume that in some few cases -mainly in communities that have accumulated carcinogenic materials from industrial and environmental pollution-, this pattern is formed as a result of accumulated risk factors or repeating a mild deviated interaction, which are lowering the genetic repair capacity, these factors may cause a low probability for some individual to be affected, just when the net pattern of a changed satellite DNA is completed. And I predict that this type of patient if treated medically, may show good prognosis with less probability of disease recurrence!

However, the deviated interactions still accused of being the main cause for the phenomenon of disease susceptibility increasing through the assumed region " inherited satellite DNA" either as a response for severe behavioral deviation or for accumulated mild behavioral deviations, since genetic destruction has increased to a degree that genetic repair cannot afford. The mechanisms that explain why a susceptible person is affected by a disease while the other is not, has been assumed in the light of genetic repair in non-controversial illustration.

It has been shown that the response is specialized, the environmental and industrial pollution affects mainly the liver and is a catalyst in the emergence of other types of cancers, deviated sexual interactions (homosexuality as example) is a major cause of the outbreak of diseases in general, and especially prostate, colorectal and lung cancers, in addition, polyandry is highly connected to cervical cancers and female insecurity is an important trigger regarding breast cancer incidence. Some of the conclusions that have been demonstrated as the relationship of family instability and the outbreak of autoimmune diseases have been consistent with the idea of trying to understand society phenomena by understanding the behavior of cells in the body 
and support the plausibility of community-human theory. In addition, the notion of HLA is a marker of a deviated ancestor of affected family line is considered very explanatory.

\section{Opposite social recommendations}

There are previous studies noticed that homosexuals has higher susceptibility to be affected by cancer than normal persons, and they recommend for providing the clinical care of homosexual people, and the education and training of healthcare. ${ }^{(135-139)}$ as a type of acceptance and legalization, which may cause increasing of the disease prevalence inadvertently.

By contrast, our study which sees the homosexuality and any type of behavioral deviation as a shape of refused obscenity, recommend following the cell-cell interaction in general, especially the $\mathrm{T}$ cell steps in their behavior with the altered or virally-infected cells which range from repair, rearrangement, anergy, and -if failed- end with inducing apoptosis.

I recommend for detecting the golden mean and their corresponding outlines regarding humanhuman interaction in order to detect the obscene interaction (exceed the limit). Every community must studied separately as a body, to solve some questions regarding their endemic disease, where the detecting an obscene interaction and eliminate it, will help in reducing the susceptibility of diseases especially cancers. It is a very low cost strategy. It's expected that the eliminating of an obscene interaction will spontaneously and reversely activates the genetic repair in the whole community DNA. It's preferred to be social decision not individual, as it is became clear that we all highly connected. This evidenced opinion review may be the way for a healthy communities in low cost strategy, if well handled!

\section{Further studies are needed}

Despite succeeding in proof of the causal relationship between behavioral deviance and disease using a cross sectional studies, the relation between satellite DNA and behavioral deviance causing increased susceptibility of diseases as an intermediate or a translator to the behavior, is just proven theoretically, therefore, this relation need a further experimental testing to be confirmed or rejected.

I recommend detecting the changes of the satellite DNA and their corresponding patterns (language of satellite DNA) that occurs in diseased individuals, thus used as a specific marker and/or a treatment target. Although it is a long time and high cost strategy, it is necessary to understand the language of satellite DNA. Therefore, I suggest studying 200 subject from a community that legalized a deviated interaction, 100 case is affected with a specific cancer and the other is healthy, but accept the deviated interaction, comparing their satellite DNA to 100 subject from a community that refuse the deviated interaction, to find the difference of satellite repeat, and detecting- if any- the pattern that reflect the increased susceptibility for this disease, another further studies are recommended to confirm that the satellite DNA is a translation to the common sense in normal human, and a translation to the deviated behavior in the behaviorally deviated human.

\section{Compliance with ethical standards}

This article does not contain any studies with human or animal subjects performed by the author. Conflict of interest: The author declare that there is no conflict of interest. 


\section{References}

1- Torre LA, Bray F, Siegel RL, Ferlay J, Lortet-Tieulent J, Jemal A. Global Cancer Statistics, 2012. CA Cancer J Clin 2015; 65:87-108.

2- Judith AO, Jenni p, Sharon AS. The major histocompatibility complex and antigen presentation. In: Kuby Immunology 7th Ed. W. H. Freeman and Company - New York.2013; P. 261.

3- Howell WM1. HLA and disease: guilt by association. Int. J. Immunogenet 2014; 41:112.

4- Rich J, Ogryzko VV, Pirozhkova IV. Satellite DNA and related diseases. Biopolym Cell 2014; 30:249-259.

5- Dicker RC, Coronado F, Koo D, Parrish RG. Introduction to Epidemiology. In: Principles of Epidemiology in Public Health Practice. 3rd Ed. U.S. Department of health and Human Services, Atianta .2012, PP.2-4.

6- Dias S, Xu W, Graves S, Kee B. Current Opinions in Genetics and Development: Transcriptional Regulation of Lymphocyte Development. Curr Opin Genet Dev 2008; 18: 441-8.

7- Judith AO, Jenni p, Sharon AS. Cells, The major histocompatibility complex and antigen presentation. In: Kuby Immunology 7th Ed. W. H. Freeman and Company $\bullet$ New York.2013; PP. 270-271.

8- Judith AO, Jenni p, Sharon AS. Cells, The major histocompatibility complex and antigen presentation. In: Kuby Immunology 7th Ed. W. H. Freeman and Company $\bullet$ New York.2013; P. 262.

9- Judith AO, Jenni p, Sharon AS. Cells, The major histocompatibility complex and antigen presentation. In: Kuby Immunology 7th Ed. W. H. Freeman and Company $\bullet$ New York.2013; P. 265.

10- Vivier E, Raulet DH, Moretta A, Caligiuri MA, Zitvogel L, Lanier LL, et al. Innate or adaptive immunity? The example of natural killer cells. Science 2011; 331:44-9.

11- Andersen MH, Schrama D, Thor Straten P, Becker JC. Cytotoxic T Cells. J Invest Dermatol 2006; 126:32-41.

12- Waring P, Müllbacher A. Cell death induced by the Fas/Fas ligand pathway and its role in pathology. Immunol Cell Biol 1999; 77:3127.

13- Kirkham LN, Nicholas R. Progress in pathology. London: Greenwich Medical Media 2001; p. 52.
14- Lodish H, Berk A, Zipursky SL, Matsudaira P, Baltimore D, Darnell JE. Molecular Cell Biology (Fifth Edition). W. H. Freeman and Company. New York, 2000; p 10.

15- Ide M, McPartlin D, Coward PY, Crook M, Lumb P, Wilson RF. Effect of treatment of chronic periodontitis on levels of serum markers of acute-phase inflammatory and vascular responses. J Clin Periodontol 2003; 30:334-40.

16- Anthea M, Hopkins J, McLaughlin CW, Johnson S, Warner MQ, LaHart D, et al. Human Biology and Health. Englewood Cliffs, New Jersey, USA: Prentice Hall. (1993).

17- Kirkby G. Waste management: three R's (reduce, reuse, recycle) reduce waste, save money. Leadersh Health Serv 1993; 2:30-3.

18- Tsigos C, Chrousos GP. Hypothalamicpituitary-adrenal axis, neuroendocrine factors and stress. J Psychosom Res 2002; 53: 865-71.

19- Gordean R, Gwathmey JK, Xie LH. Autonomic and endocrine control of cardiovascular function. World $\mathrm{J}$ cardiol 2015; 7: 204-14.

20- Chaplin DD. Overview of the Immune Response. J Allergy Clin Immunol 2010; 125: 3-23.

21- Judith AO, Jenni p, Sharon AS. Cells, organs and microenvironment of the immune system. In: Kuby Immunology 7th Ed. W. H. Freeman and Company. New York.2013; PP. 41-43.

22- Burdick MM, McCarty OJ, Jadhav S, Konstantopoulos K. The role of the CellCell Interactions in Inflammation and Cancer Metastasis. Engineering in Medicine and Biology Magazine 2001; 20: 86-91.

23- Judith AO, Jenni p, Sharon AS. Cells, T-Cell Activation, Differentiation, and Memory. In: Kuby Immunology 7th Ed. W. H. Freeman and Company. New York.2013; P. 359.

24- Richard M. Biomarkers: Potential Uses and Limitations. NeuroRx. 2004; 1: 182-8.

25- Mergenthaler P, Lindauer U, Dienel GA, Meisel A. Sugar for the brain: the role of glucose in physiological and pathological brain function. Trends Neurosci 2013; 36: 587-97.

26- Peter L P. Aristotle's ethics: all four of them. Philosophia, Philippines 2014; 15: 131. 
27- Haroon AM. Ibn El-Fares Dictionary of Language Standards. $1^{\text {st }}$ Ed. Dar El-fekr. Damascus1979; Part 4 P. 478.

28- Thygesen LC, Andersen GS, Andersen H. A philosophical analysis of the Hill criteria. J Epidemiol Community Health 2005 Jun; 59: 512-6.

29- Evans AS. Causation and Disease: The Henle-Koch Postulates Revisited. Yale J Biol Med. 1976; 49: 175-95.

30- Hill AB. The environment and disease: Association or causation? Proc R Soc Med. 1965; 58: 295-300.

31- Vicki B. Connecting Viruses to Cancer: How Research Moves From Association to Causation. J Natl Cancer Inst 2004; 96: 2567.

32- Young TK. Assessing health risk in populations. In: Population health: concepts and methods. $1^{\text {st }}$ Ed. New York: Oxford University Press, 1998:PP143-9.

33- MacMahon B, Trichopoulos D. Epidemiology: principles and methods. $2^{\text {nd }}$ ed. Boston: Little Brown 1996:19-29.

34- Bhopal RS. Cause and effect: the epidemioloical approach. In: Concepts of epidemiology - an integrated introduction to the ideas, theories, principles and methods of epidemiology. Oxford: Oxford University Press, 2002:98-132.

35- Danaei G, Vander Hoorn S, Lopez AD, Murray CJ, Ezzati M; Comparative Risk Assessment collaborating group (Cancers). Causes of cancer in the world: comparative risk assessment of nine behavioural and environmental risk factors. Lancet 2005 19; 366:1784-93.

36- Foulkes WD. Inherited susceptibility to common cancers. N Engl J Med 2008; 359:2143-53.

37- Youlden DR, Cramb SM, Baade PD. The International Epidemiology of Lung Cancer: geographical distribution and secular trends. J Thorac Oncol 2008; 3: 819-31.

38- Eriksen M, Mackay J, Schluger N, Gomeshtapeh FI, Drope J. The tobacco atlas. 5th ed. Atlanta: American Cancer Society; 2015.

39- Lozano R, Naghavi M, Foreman K, et al. Global and regional mortalityfrom 235 causes of death for 20 age groups in 1990 and 2010: a systematic analysis for the Global Burden of Disease Study 2010. Lancet 2012; 380: 2095-128.
40- Ames BN, Gold LS. The causes and prevention of cancer: the role of environment. Biotherapy 1998; 11:205-20.

41- Gold LS, Slone TH, Ames BN. Overview and update analyses of the carcinogenic potency database, in: Gold LS and Zeiger E, eds., Handbook of Carcinogenic Potency and Genotoxicity Databases, Boca Raton, FL: CRC Press, 1997;pp. 661-85.

42- Ames BN, Profet M, Gold LS, Nature's chemicals and synthetic chemicals: Comparative toxicology, Proc Natl Acad Sci USA 1990; 87: 7782-6.

43- Naoyo N, Hirohisa Y, Takashi N, Toshiharu $\mathrm{K}$, Masamichi K. Angiogenesis in Cancer. Vasc Health Risk Manag 2006; 2: 213-9.

44- Simon M, Pawlotsky Y, Bourel M, Fauchet R,Genetet B. Idiopathic hemochromatosis: disease associated with tissue antigen. Nouv Presse Med 1975; 4:1432.

45- Feder JN, Gnirke A, Thomas W, Tsuchihashi Z, Ruddy DA, Basava A, et al. A novel MHC class I-like gene is mutated in patients with hereditary haemochromatosis. Nat Genet 1996; 13:399-408.

46- Terasaki PI. HLA in paternity testing. West J Med 1978; 128:48.

47- Larsen CE, Alper CA. The genetics of HLAassociated disease. Curr Opin Immunol 2004; 16: 660-7.

48- Goldenfeld N, Woese C. Life is physics: evolution as a collective phenomenon far from equilibrium. Annu Rev Condens Matter Phys 2011; 2:375-99.

49- Ohno S. So much «junk» DNA in our genome. Brookhaven Symp Biol 1972; 23:366-70.

50- de Koning AP, Gu W, Castoe TA, BatzerMA, Pollock DD. Repetitive elements may comprise over two-thirds of the human genome. PLoS Genet. 2011; 7:e1002384.

51- Tremblay DC, Alexander G Jr, Moseley S, Chadwick BP. Expression, tandem repeat copy number variation and stability of four macrosatellite arrays in the human genome. BMC Genomics.2010; 11:632.

52- Turnpenny PD, Ellard S. The Cellular and Molecular Basis of Inheritance. In: Emery's Elements of Medical Genetics. 14th Ed. Philadelphia, Elsevier. 2012; p 17.

53- Balog J, Miller D, Sanchez-Curtailles E, Carbo-Marques J, Block G, Potman M, et al. Epigenetic regulation of the $\mathrm{X}$-chromosomal macrosatellite repeat encoding for the 
cancer/testis gene CT47. Eur J Hum Genet. 2012; 20:185-91.

54- Khurana E, Fu Y, Colonna V, Mu XJ, Kang $\mathrm{HM}$, Lappalainen $\mathrm{T}$, et al. Integrative annotation of variants from 1092 humans: application to cancer genomics. Science 2013; 342:1235587.

55- Nobrega MA, Zhu Y, Plajzer-Frick I, Afzal V, Rubin EM. Megabase deletions of gene deserts result in viable mice. Nature 2004; 431:988-93.

56- Pheasant M, Mattick JS. Raising the estimate of functional human sequences. Genome Res 2007; 17(9):1245-53.

57- Wright FA, Lemon WJ, Zhao WD, Sears R, Zhuo D, Wang J, et al. A draft annotation and overview of the human genome. Genome Biol 2001; 2: research0025.1research0025.18.

58- Minovitsky S, Gee SL, Schokrpur S, Dubchak I, Conboy JG. The splicing regulatory element, UGCAUG, is phylogenetically and spatially conserved in introns that flank tissue-specific alternative exons. Nucleic Acids Res 2005; 33:714-24.

59- Barash Y, Calarco JA, Gao W, Pan Q, Wang $\mathrm{X}$, Shai $\mathrm{O}$, et al. deciphering the splicing code. Nature 2010; 465: 53-9.

60- Hoeppner MP, White S, Jeffares DC, Poole AM. Evolutionarily stable association of intronic snoRNAs and microRNAs with their host genes. Genome Biol Evol 2009; 1:420-8.

61- Baskerville S, Bartel DP.Microarray profiling of microRNAs reveals frequent coexpression with neighboring miRNAs and host genes. RNA 2005; 11: 241-7.

62- Alotaibi H, Yaman E, Salvatore D, Di Dato V, Telkoparan P, Di Lauro R, et al. Intronic elements in the Na+/I-symporter gene (NIS) interact with retinoic acid receptors and mediate initiation of transcription. Nucleic Acids Res 2010; 38: 3172-85.

63- Lavrov SA, Kibanov MV. Noncoding RNAs and chromatin structure. Biochemistry (Mosc) 2007; 72: 1422-38.

64- Sorge J, Gross E,West C, Beutler E. High level transcription of the glucocerebrosidase pseudogene in normal subjects and patients with Gaucher disease. J Clin Invest 1990; 86: 1137-41.

65- Schmutzler C, Gross HJ. Genes, variant genes, and pseudogenes of the human tRNA(Val) gene family are differentially expressed in HeLa cells and in human placenta. Nucleic Acids Res. 1990; 18: 5008.

66- Watanabe T, Totoki Y, Toyoda A, Kaneda M, Kuramochi-Miyagawa S, Obata Y, et al. Endogenous siRNAs from naturally formed dsRNAs regulate transcripts in mouse oocytes. Nature. 2008; $453: 539-43$.

67- Lebre AS, Jamot L, Takahashi J, Spassky N, Leprince C, Ravisé N, et al. Ataxin-7 interacts with a Cbl-associated protein that it recruits into neuronal intranuclear inclusions. Hum Mol Genet 2001; 10:120113.

68- Vergnaud G, Denoeud F. Minisatellites: mutability and genome architecture. Genome Res 2000; 10: 899-907.

69- Abdul-Muneer PM. Application of microsatellite markers in conservation genetics and fisheries management: recent advances in population structure analysis and conservation strategies. Genet Res Int 2014; 2014:691759.

70- Rudd MK, Mays RW, Schwartz S, Willard HF. Human artificial Chromosomes with alpha satellite-based de novo centromeres show increased frequency of nondisjunction and anaphase lag. Mol Cell Biol 2003; 23: 7689-97.

71- Kim JH, Ebersole T, Kouprina N, Noskov VN, Ohzeki J, Masumoto H, et al. Human gamma-satellite DNA maintains open chromatin structure and protects a transgene from epigenetic silencing. Genome Res 2009; 19: 533-44.

72- Hood E. RNAi: What's all the noise about gene silencing? Environ Health Perspect 2004; 112:A224-9.

73- Balog J,Miller D, Sanchez-Curtailles E, Carbo-Marques J, Block G, Potman M, et al. Epigenetic regulation of the $\mathrm{X}$-chromosomal macrosatellite repeat encoding for the cancer/testis gene CT47. Eur J Hum Genet. 2012; 20: 185-91.

74- Geng LN, Yao Z, Snider L, Fong AP, Cech JN, Young JM, et al. DUX4 activates germline genes, retroelements, and immune mediators: implications for facioscapulohumeral dystrophy. Dev Cell 2012; 22: 38-51.

75- Djian P. Evolution of simple repeats in DNA and their relation to human disease. Cell 1998; 94: 155-0. 
76- Mirkin SM. Expandable DNA repeats and human disease. Nature 2007; 447: 932-40.

77- Mirkin SM. DNA structures, repeat expansions and human hereditary disorders. Curr Opin Struct Biol 2006; 16: 351-8.

78- Zoghbi HY, Orr HT. Glutamine repeats and neurodegeneration. Annu Rev Neurosci 2000; 23:217-47.

79- Harper PS, Harley HG, Reardon W, Shaw DJ. Anticipation in myotonic dystrophy: new light on an old problem. Am J Hum Genet 1992; 51: 10-6.

80- Richards RI, Sutherland GR. Heritable unstable DNA sequences. Nat Genet 1992; 1: 7-9.

81- Burgess DJ. Chromosome instability: Tumorigenesis via satellite link. Nat Rev Cancer 2011; 11: 158.

82- Narayan A, Ji W, Zhang XY, Marrogi A, Graff JR, Baylin SB, Ehrlich M. Hypomethylation of pericentromeric DNA in breast adenocarcinomas. Int $\mathrm{J}$ Cancer 1998; 77: 833-8.

83- Wang XW, Grisham JW, Thorgeirsson SS. Molecular Genetics of Liver Neoplasia. Springer. New York 2010; 399 p.

84- Srikanta S, Ganda OP, Jackson RA, Gleeson RE, Kaldany A, Garovoy MR, et al. Type 1 diabetes mellitus in monozygotic twins: chronic progressive 0 cell dysfunction. Ann Int Med 1983; 99:320-326.

85- Leslie RD, Hawa M. Twin studies in autoimmune disease. Acta Genet Med Gemellol (Roma) 1994; 43: 71-81.

86- Lahtz C, Pfeifer GP. Epigenetic changes of DNA repair genes in cancer. $\mathbf{J}$ Mol Cell Biol 2011; 3:51-8.

87- Torgovnick A, Schumacher B. DNA repair mechanisms in cancer development and therapy. Front Genet. 2015; 6:157.

88- Judith A.O., Jenni p, Sharon AS. Cells, The major histocompatibility complex and antigen presentation. In: Kuby Immunology 7th Ed. W. H. Freeman and Company $\bullet$ New York.2013; P. 274.

89- Miller v. California (1973). Retrieved October 29, 2008.http://www.law.umkc.edu/faculty/proj ects/ftrials/conlaw/miller.hmtl

90- Baghramian M , Carter JA. (2015, September 11). Relativism. Retrieved from www. plato.stanford.edu

91- Baghramian M. Relativism about science. (2008,
January31).www.routledge.com/books/detail s/9780203000502/

92- Judith Silver E. (2001) Movie Day at the Supreme Court "I Know It When I See It": A History of the Definition of Obscenity Retrieved from jsilver@ coollawyer.com

93- Jacobellis v. Ohio, 378 U.S. 184, 197 (1964)

94- Anwar WA. Environmental Health in Egypt. Int. J. Hyg Environ Health 2003; 206: 339 50.

95- Donia D, El-Azizy I, Khalifa A. Industrial Pollution Control of Rosetta Branch, Nile River, EGYPT. Seventh International Water Technology Conference Egypt 2003; 23547.

96- Shepard CW, Finelli L, Alter MJ. Global epidemiology of hepatitis $C$ virus infection. Lancet Infect Dis 2005; 5:558-67.

97- Ballester JM, Rivero RA, Villaescusa R, Merlin JC, Arce AA, Castillo D,et al. Hepatitis $\mathrm{C}$ virus antibodiesand other markers of blood-transfusion-transmitted infection in multi-transfused Cuban patients. J Clin Virol 2005; 34:S39-S46.

98- Mahmoud YA, Mumtaz GR, Riome S, Miller D, Abu-Raddad LJ. The epidemiology of hepatitis $C$ virus in Egypt: a systematic review and data synthesis. BMC Infect Dis. 2013; 13: 288.

99- Freedman LS, Edwards BK, Ries LA., YOUNG JL. Executive Summary. In:Cancer Incidence in Four Member Countries (Cyprus, Egypt, Israel, and Jordan) of the Middle East Cancer Consortium (MECC) Compared with US SEER. National Cancer Institute. NIH Pub. No. 06-5873. Bethesda, MD. at http://seer.cancer.gov

100- Ferlay J, Shin HR, Bray F, Forman D, Mathers $\mathrm{C}$ and Parkin DM. GLOBOCAN 2008 v2.0, Cancer Incidence and Mortality Worldwide: IARC CancerBase No. 10 [Internet]. Lyon, France: International Agency for Research on Cancer; 2010. Available from: http://globocan.iarc.fr

101- Applewhite N, Pulitzer Center staff. (2012, December 03 )Cancer's Global Footprint. Retrieved from www. pulitzercenter.org

102-Vermeulen K, Berneman ZN, Van Bockstaele DR. Cell cycle and apoptosis. Cell Prolif 2003; 36:165-75.

103-Lockshin RA, Williams CM. Programmed cell death-I.Cytology of degeneration in the intersegmental muscles of the Pernyi silkmoth. J Insect Physiol 1965; 11:123-33. 
104-Hassan M, Watari H,AbuAlmaaty A, Ohba Y, Sakuragi N. Apoptosis and molecular targeting therapy in cancer. Biomed Res Int 2014; 2014:150845.

105-Massoud M.F, op cit n.5 at page 301.

106- Ilyayambwa M. Homosexual Rights and the Law: A South African Constitutional Metamorphosis. International Journal of Humanities and Social Science 2012; 2:508.

107-Dhiraj AB. (2015, November 11). List of countries where same-sex marriage is legal. Retrieved from www.ceoworld.biz

108-CIA The World Factbook: Population growth rate. Retrieved 11/08/2015.

109-Bradshaw D, Groenewald P, Laubscher R, Nannan N, Nojilana B, Norman R, et al. Initial burden of disease estimates for South Africa, 2000. S Afr Med J 2003; 93: 682-8.

110-Ferlay J, Soerjomataram I, Ervik M, Dikshit R, Eser S, Mathers C, Rebelo M, Parkin DM, Forman D, Bray, F.GLOBOCAN 2012 v1.0, Cancer Incidence and Mortality Worldwide: IARC CancerBase No. 11 [Internet]. Lyon, France: International Agency for Research on Cancer; 2013. Available from: http://globocan.iarc.fr, accessed on 3/8/2017.

111-Robertson SA, Sharkey DJ. The role of semen in induction of maternal immune tolerance to pregnancy. Semin Immunol 2001; 13:243-54.

112-"The five most improved places for gay tolerance". The Independent. London. 17 September 2008. Retrieved from :www.independent.co.uk

113- Ferlay J, Shin HR, Bray F, Forman D, Mathers C, Parkin DM. Estimates of worldwide burden of cancer in 2008: GLOBOCAN 2008. Int J Cancer. 2010; 127:2893-917.

114-Breast Cancer Facts \& Figures 2015-2016. Published in the American Cancer Society journal, CA: A Cancer Journal for Clinicians. Available at: www.cancer.org

115-Sprague BL, Trentham-Dietz A, Gangnon RE, Ramchandani R, Hampton JM, Robert $\mathrm{SA}$, et al. Socioeconomic status and survival after an invasive breast cancer diagnosis. Cancer 2011; 117: 1542-51.

116-Safest U.S. States - Just Thought You Should Know. Available at: www.justthoughtyoushouldknow.org
117-Cassidy ML, Lee GR, The study of polyandry: A critique and synthesis. Journal of Comparative Family Studies1989; 20: 111.

118-Haddix KA. Leaving your wife and your brothers: when polyandrous marriages fall apart. Evol Hum Behav 2001; 22:47-60.

119-Zhang T. Population in Tibet: its past, present, and prospects. Chin J Popul Sci 1994; 6:367-85.

120- Raha MK. Polyandry in India: retrospect and prospect. Man India. 1991; 71:163-81.

121- Mulder MB. Serial monogamy as polygyny or polyandry? : Marriage in the tanzanian pimbwe. Hum Nat. 2009; 20:130-50.

122- Chigiti J. (2013, October 2). Polygamy and polyandry. Retrieved from www.thestar.co.ke

123-Dreger A. (2013, February 1). When Taking Multiple Husbands Makes Sense. Retrieved from www. theatlantic.com

124-Starkweather K. Preliminary Survey of Lesser-Known Polyandrous Societies. Nebraska Anthropologist 2009; 50: 16-35.

125-Johnson H. There are Worse Things than Being Alone: Polygamy in Islam, Past, Present, and Future. William and Mary Journal of Women and the Law 2005; 11: 562-596.

126-Ervik M, Lam F, Ferlay J, Mery L, Soerjomataram I, Bray F. (2016). Cancer Today. Lyon, France: International Agency for Research on Cancer. Cancer Today. Available from: http://gco.iarc.fr/today, accessed [6/8/2017].

127- Kennedy S, Fitch CA. Measuring cohabitation and family structure in the United States: assessing the impact of new data from the Current Population Survey. Demography 2012; 49:1479-98.

128-Cherlin A. Demographic Trends in the United States: A Review of Research in the 2000s. J Marriage Fam 2010; 72:403-419.

129-Manning Wendy D, Smock Pamela J, Bergstrom-Lynch Cara. Cohabitation and Parenthood: Lessons from Focus Groups and in-Depth Interviews. In: Peters Elizabeth H, Kamp Dush Clair M., editors. Marriage and Family: Perspectives and Complexities. New York: Columbia University Press 2009. pp. 115-142.

130-Carlson MJ, Berger LM. What Kids Get from Parents: Packages of Parental 
Involvement across Complex Family Forms. Soc Serv 2013; 87:213-49.

131-Manning WD. Cohabitation and Child Wellbeing. Future Child 2015; 25:51-66.

132-Fomby P, Osborne C. The Influence of Union Instability and Union Quality on Children's Aggressive Behavior. Soc Sci Res 2010; 39: 912-24.

133-Gubernskaya Z. Attitudes toward Cohabitation in 28 Countries: Does Marital Status Matter? University of California, Irvine.

134-Lerner A, Jeremias P, Matthias T. The World Incidence and Prevalence of Autoimmune Diseases is Increasing. International Journal of Celiac Disease 2015; 3: 151-5.

135-Daling JR, Weiss NS, Klopfenstein LL, Cochran LE, Chow WH, Daifuku R. Correlates of homosexual behavior and the incidence of anal cancer. JAMA 1982; 247:1988-90.

136-Lee R. Health care problems of lesbian, gay, bisexual, and transgender patients. West $\mathbf{J}$ Med 2000; 172: 403-8.

137-Boehmer U, Miao X, Ozonoff A. Cancer survivorship and sexual orientation. Cancer 2011; 117:3796-804.

138- Burkhalter JE, Margolies L, Sigurdsson HO, Walland J, Radix A, Rice D, et al. The National LGBT Cancer Action Plan: A White Paper of the 2014 National Summit on Cancer in the LGBT Communities. LGBT Health 2016; 3: 19-31.

139-Simon Rosser BR, Merengwa E, Capistrant $\mathrm{BD}$, Iantaffi A, Kilian G, Kohli N, et al. Prostate Cancer in Gay, Bisexual, and Other Men Who Have Sex with Men: A Review. LGBT Health 2016; 3: 32-41. 